NBER WORKING PAPER SERIES

U.S. AND FOREIGN COMPETITION

IN THE DEVELOPING COUNTRIES

OF THE ASIAN PACIFIC RIM

Robert E. Baldwin

Working Paper No. 2208

NATIONAL BUREAU OF ECONOMIC RESEARCH

1050 Massachusetts Avenue

Cambridge, MA 02138

Apri1 1987

The research reported here is part of the NBER's research program in International studies. Any opinions expressed are those of the author and not those of the National Bureau of Economic Research. 


\title{
U.S. and Foreign Competition in the Developing \\ Countries of the Asian Pacific Rim
}

\begin{abstract}
This paper examines changes since the early 1960 s in the export shares of the United States and its major competitors in the markets of the developing. countries of the Asian Pacific Rim (APR), defined to include Hong Kong, Korea, Taiwan, Singapore, the Philippines, Malaysia, Thailand, Indonesia, and China. A technique for revealing a country's factor-price advantages or disadvantages in its trade with another country is also used to analyze the U.S. comparative cost position relative to the countries of the region. Among the findings are that the U.S. export share in the APR market has remained roughly constant over the period and that the United states has a relative factor-price advantage with all the developing countries of the region in physical capital and skilled labor and a disadvantage in unskilled labor. For land and natural resources, the picture is mixed.

The competitive performance of these developing countries in the markets of the United States, Canada, Japan, the European Community, Australia and New Zealand, and in the region itself is also studied, revealing the familiar result that the developing countries of the region and Japan have increased their market shares significantly since the 1960s. In addition, the volume and distribution of U.S. and Japanese direct investment in the Asian Pacific Rim is examined.
\end{abstract}

Robert E. Baldwin

Department of Economics University of Wisconsin Madison, WI 53706 
U.S. AND FOREIGN COMPETITION IN THE DEVELOPING COUNTRIES

OF THE ASIAN PACIEIC RIM

Robert E. Baldwin

\section{INTRODUCTION ${ }^{1}$}

The ability of the major developing countries of the Asian Pacific Rim (APR) - Hong Kong, the Republic of Korea (henceforth referred to as Korea), the Republic of China (henceforth referred to as Taiwan), the Philippines, Malaysia, Singapore, Thailand, Indonesia, and the People's Republic of China (henceforth referred to as China) - to compete in the markets of the United States is well-known and frequently cited by many domestic industries as a matter for national concern. Much less is known about the competitive performance and potential of American industries in the markets of the major developing countries of the APR and interest in this matter is only beginning to develop; ${ }^{1}$ it will be the focus of this paper.

The following section provides an economic overview of the APR by comparing the main economic characteristics of the countries in the region and those of the region as a whole with other major groupings of countries. Since the prospects for exporting goods and services to the countries of the region depend on the policies these countries follow in such matters as

1 I am indebted to Jeffrey steagall for research assistance in preparing the paper and also to Gary sampson of the United Nations Conference on Trade and Development in Geneva for providing the export and import data on the developing countries of the Asian Pacific Rim. 
promoting economic growth and the opening of domestic markets, the third section briefly describes the economic policies pursued by each APR country in the recent past. This section also analyzes the success of major trading partners in penetrating the market for imports in each country and how successful each country has been in exporting to major foreign markets. Finally, the trade and development policies likely to be followed in the future in each country is briefly discussed in section three.

section four analyzes the competitive performance of the United states and its major competitors in the markets for imports in three groups of APR countries: the advanced developing countries (ADCs) of the region - Hong Kong, Korea, Taiwan, and Singapore; the resource-rich countries (RRCs) of the region - the Philippines, Malaysia, Thailand, and Indonesia; and China. It also examines changes since the early 1960s in the shares of the import markets in these APR country groups captured by the United states, Canada, Japan, the European Community, Australia and New zealand, and other countries within the region, together with changes in the commodity composition of exports to the APR groups from these countries and country-groups. A technique for revealing the sources of a country's comparative advantage is used to determine the relative factor-price advantages and disadvantages the United states has in its trade with the countries of the region.

Section five briefly looks at the performance of the three APR country groups in exporting to the United states and other 
major foreign markets and examines changes since the early 1960s in the share of their exports absorbed by the United states and other countries and shifts in the commodity composition of their exports.

Because trade and investment are closely linked, it is necessary to take foreign investment into account in evaluating U.S. competitive prospects in the region. Section six examines the volume and country distribution of direct foreign investment in the region by the United states and its main competitor in the area, Japan. Changes in the relative importance of U.S. direct investment in different sectors in the APR countries are also studied. The final section summarizes the main conclusions of the paper.

\section{AN OVERVIEW OF ECONOMIC CHARACTERISTICS AND PERFORMANCE}

\subsection{The Developing Countries of APR Compared to other Regions}

The tremendous market potential in the developing countries of the Asian Pacific Rim lies simply in their being not only the most populous but the fastest growing region of the world. The population of the nine countries totals 1.33 billion, whereas that of the next most populous region, South Asia, amounts to .87 billion. Gross national product (GNP) per capita in the nine countries grew at a remarkable average rate of $5.75 \%$ between 1965 and 1984. In contrast, GNP per capita in the industrial marketeconomy countries increased at an average rate of only $2.5 \%$ during this period and at average rates of $1.9 \%$ in both South 
Asia and the countries of South America (World Development Report 1986, Annex Table 1).

Table 1 compares the APR countries with a selected group of countries outside of the area in terms of basic economic characteristics and performance indicators. Except for the Philippines, per capita income grew much more rapidly in the developing countries of the Asian Pacific Rim than in mature developed countries such as the United states and West Germany and, in most cases, even Japan, the newest and most dynamic developed country. Yet, though per capita income levels in the APR countries rank among the highest for all developing nations, there is still a wide per capita income gap between the advanced industrial market economies and these countries. West Germany's 1984 per capita income, for example, is more than five times as large as South Korea's and almost seventeen times as large as the Philippines per capita income in that year.

The magnitude of the APRs output and imports is also small when compared to that of the developed countries. The total of all nine countries gross domestic product in 1984 was $\$ 656$ billion, only slightly more than one-half of Japan's and not much greater than West Germany's GDP. The difference in imports is less striking due to the high degree of dependence on trade of most countries in the region. Their total 1984 imports of $\$ 181$ billion are roughly equal to those of Japan and of West Germany in that year. Thus, the major market opportunities for the United States are still in other developed countries; the major 
developing countries of Southeast Asia and East Asia represent an important potential market rather than a major current one.

Compared with other developing regions, however, the developing countries of the Asian Pacific Rim already rank as the largest market. The $1984 \$ 656$ billion GDP level of the region compares with GDP levels of $\$ 623$ billion for all of South America, Central America, and the Caribbean and of \$406 billion for South Asia, for example. Moreover, the 1984 \$181 billion import level of the region compares with only $\$ 64$ billion for South America, Central America, and the Caribbean and $\$ 25$ billion for South Asia. This market-size advantage is likely to widen during the rest of the century, given the currently higher growth rates in the Pacific Rim countries.

Table 2 shows the growth and trade experience of the APR and selected other countries before and after the first oil crisis. The general slowdown in growth in both the developing and developed countries after the first oil shock is evident from the table. It should be noted, however, that the relative decline in growth rates has been less in the APR countries than in such developed countries as the United States, Japan, and Germany. In the United States, the percentage decline in the average annual growth rate of GDP between $1965-73$ and 1973-84 was 28\%; in Japan, $56 \%$; and in Germany, 57\%. The average annual GDP growth rate actually increased in Hong Kong and Malaysia (also India) and declined by only $18 \%$ on the average in the other seven developing countries in the Asian Pacific Rim. 


\subsection{Diversity among the APR Countries}

As shown in Table 1 , there are significant economic differences among the developing countries of the Asian Pacific Rim. It is usual to divide the countries into three groups, the first comprising South Korea, Taiwan, Hong Kong, and Singapore; the second consisting of the Philippines, Malaysia, Thailand, and Indonesia; and the third being China. The first group is usually designated the "newly industrializing countries" (NICs) of Asia, a term indicating their relatively early emphasis on exportoriented industrialization. While the words, "newly industrializing," were appropriate in the 1960s and early 1970s when they first adopted policies aimed at significantly increasing the exports of manufactures, it seems more appropriate to use Hong and Krause's (1981) term, "advanced developing countries" (ADCs), especially since other countries of the region later also adopted policies aimed at export-oriented industrialization. Per capita income in all of the ADCs is higher than in the countries of the other two groups, though if per capita income alone is the basis of the classification, it would seem reasonable to include Malaysia in the first group. There is also a significant gap between income levels in Singapore and Hong Kong and in Taiwan and South Korea.

The second group of four nations is usually described as the resource-rich countries (RRCs) to indicate the much greater share of primary products in their exports compared to the ADCs (see Table 3$)^{2}$. The greater share of production devoted to 
agriculture is an indication of their greater land resources as well as their lower per capita income levels. Except for Malaysia, the RRCs are less open than the ADCs of Asia in terms of trade's share of GDP, and these countries have pursued importsubstitution policies more vigorously than the ADCs. Another difference is the higher natural rate of population growth in the RRCs than in the ADCs. ${ }^{3}$

China is unique in several respects. It is by far the most populous country in the world and it ranks third in area. Though it has become much more outward-looking in recent years it remains, as the export and import shares presented in Table 1 indicate, a very closed economy compared to other countries in the region, although not in comparison to such countries as India and the United states. While its GDP growth rate since 1965 compares favorably. with the RRCs', China's low per capita income level makes the country more similar to the countries of south Asia than to those of the Asian Pacific Rim.

\subsection{Savings Investment, Foreign Debt, and Trade Adjustment}

A necessary, though not sufficient, requirement for a country to raise its growth rate is to increase its investment and savings rates significantly. As Table 4 shows, such an increase has occurred in the ADCs, the RRCs and China. In five of the nine countries, investment as a share of GDP rose by more than ten percentage points between 1960 and 1984, and in three others the increase was at least five percentage points. The 1984 investment ratio in Singapore was an incredible 47 percent, 
and it was 30 percent or more in Taiwan, Malaysia, and China. The increase in domestic savings has been even more impressive, especially in Singapore, Hong Kong, Taiwan, South Korea, and Indonesia. The rate of gross domestic savings is now about 30 percent or more in six of the nine countries. The only developed countries that can match these savings rates are Japan (31 percent) and Norway (35 percent).

An excess of domestic investment over domestic savings indicates that savings by foreigners are financing part of a country's investment activities. Such was the case for the ADCs in the initial phases of their take-off to high rates of growth, as the figures in Table 4 on the resource gap indicate. The large positive number for Hong Kong in 1984 indicates that domestic savers were investing some of their savings abroad, probably because of their uncertainty about the political future of the colony.

A more direct indication of the extent to which a country has relied on external sources of finance is the magnitude of its external debt and the ratio of the external debt to the country's GNP. The debt-service share of exports of goods and services is a rough indicator of the degree of difficulty the country has in meeting its external obligations. Table 5 presents information on these various debt indicators for the APR countries, except for China, on which debt data are unavailable. As with developing countries generally, the data show a very rapid increase in external borrowing for APR countries over the last 15 
years. This ability to draw upon external sources, especially private capital markets, has been an important factor in enabling growth to continue at high rates. It has, however, also led to serious debt-servicing problems for some nations that borrowed heavily and then around 1980 were suddenly faced both with much higher real interest rates and falling prices for their export products. Four APR countries - South Korea, Thailand, the Philippines, and Indonesia - are on most lists of countries faced with significant debt-servicing problems; debt-servicing charges in 1984 claimed more than 15\% of the foreign exchange they earned from exporting goods and services. The drain of debt-servicing on the foreign exchange earnings of Singapore and Hong Kong is negligible and only about 5\% for Taiwan and Malaysia.

Obviously, in order to cope with increased debt-servicing charges, a country. must generate additional foreign exchange by improving its balance of trade. Table 6 shows that the trade balance of the four main indebted countries, South Korea, Thailand, the Philippines, and Indonesia improved between 1983 and 1985. Korea, whose balance of trade has improved steadily since 1981, achieved the most desirable type of trade adjustment between these years - an expansion of imports and exports. Thailand's improved trade balance between 1983 and 1985 came about through an expansion of exports and contraction of imports. The recent trade adjustment in both the Philippines and Indonesia was achieved by reducing both exports and imports. 


\section{DEVELOPMENT POLICY AND TRADE PERFORMANCE}

As with most developing countries in the world, the major economic goal of those in the Asian Pacific Rim over the last 40 years has been to increase the rate of economic development. Their success in achieving this goal and the extent to which their development policies involve a willingness to open their own markets to the products of other countries largely determine the trading opportunities of the United States and others in the region. This section briefly describes the nature of the development strategies pursued by the individual APR countries and analyzes the shifts that have taken place in the commodity composition and geographical distribution of their exports and imports. It also speculates as to each country's likely future trade and development policies.

\section{1 The Advanced Developing Countries}

\subsubsection{Hong Kong}

\subsubsection{Trade and Development Policy *}

The British colony of Hong Kong is unique among developing economies in that it has achieved its remarkable post-World War II growth under a policy of "positive nonintervention." Imports and exports of both goods and capital have been completely free from government taxes, subsidies, or other controls, and no effort has been made to direct investment into particular sectors. The standard tax rate on earnings and profits is the lowest of any industrial state, being set at the level of $12.5 \%$ 
from 1951-1966.

Until the early 1950s, Hong Kong's prosperity was based on re-exporting products from south China throughout the world and serving as an entry port for foreign products destined for the mainland. Two external events in the 1950s disrupted this entrepot role. The first was the change of government as the Communists took control of the mainland. Their inward-looking policies resulted in a significant diminution in China's trade with Hong Kong. Dissatisfaction with the new government led to massive emigration from China to Hong Kong that increased the colony's population by almost $50 \%$ in a few years. The second event that reduced Hong Kong's role as a trade facilitator was the United Nations embargo imposed on China because of its role in the Korean War.

Fortunately, the Chinese immigrants included entrepreneurs who had both industrial experience, especially in textiles, and the capital necessary to establish manufacturing activities. Utilizing the abundant supply of low-wage workers that also became available through immigration; these individuals spearheaded the shift in Hong Kong's economic structure from that of entrepot to exporter of labor-intensive manufactured products. The industrialization effort was also helped by the existence of an excellent infrastructure of port, banking, insurance, and shipping facilities, and a long history of commercial ties with overseas traders. Manufacturing employment increased from 82,000 in 1950 to 216,000 in 1960, while the share of re-exports in 
total exports declined from $88 \%$ to $27 \%$ in that decade.

\subsubsection{Trade Performance}

As can be seen from Table 7 , which indicates the colony's pattern of exports and imports in 1960, 1978 and 1983, Hong Kong has gradually diversified its manufacturing activities and, in particular, reduced its dependence on textiles and clothing. Exports in the machinery and transport equipment category have become significant. The diversification has been due in part to the efforts of the government, which, beginning in the late 1970s, backed away somewhat from its hands-off policy and began to arrange industrial support facilities and technical services to facilitate the shift toward more capital-intensive, high-skill manufacturing sectors.

A more detailed breakdown of the composition of Hong Kong' $s$ trade with its major trading partners is presented in Table 8. Between 1963 and 1980 both the United States and Japan moderately increased their share of the combined exports to Hong Kong by the United States, Canada, Japan, Australia and New Zealand, the European Community, other ADCs; the RRCs in the region, and China. The U.S. share increased from $16 \%$ to $18 \%$. The countries that increased their export share the most, however, were the other ADCs, i.e., Taiwan, Korea, and Singapore; their share rose from $8 \%$ to $16 \%$ between these years despite the exclusion from the figures of exports from Taiwan to Hong Kong in 1980 (and 1984). The European Community and the four resource-rich countries - the Philippines, Malaysia, Thailand, and Indonesia, were the losers 
in terms of export shares between 1963 and 1980 .

The major change between 1980 and 1984 was the emergence of China as a major supplier to the Hong Kong market. In 1984 almost $30 \%$ of exports to Hong Kong came from China. Of course, much of this reflects the re-emergence of entrepott trade for Hong Kong as China became more open. The U.S. market share declined about a third between 1980 and 1984 (from 18\% to $12 \%$ ), due no doubt in part to the appreciation of the dollar relative to other major currencies after 1980. Japan's share also declined between these years but less in relative terms than the U.S. share.

Table 8 also shows the country/region distribution of Hong Kong's own exports between 1963 and 1984. The share of exports to the United States increased from $35 \%$ in 1963 to $50 \%$ in 1970 and then declined to $41 \%$ by the end of the 1970s, a decade in which the dollar depreciated. As the dollar appreciated in the early 1980s, the share of Hong Kong's exports absorbed by the United States again rose to $50 \%$. Remarkably, the share of exports absorbed by Japan remained at about $4 \%$ over the entire period. The trend in the EC share was downward over the period with an especially sharp fall evident after 1980.

The main factor in Hong Kong's long-term economic outlook is the coming return of sovereignty to China in 1997. The agreement reached in 1984 between Great Britain and China called for the maintenance of Hong Kong's market-oriented economy for at least 50 years after 1997, but, despite this provision, there is understandably a great deal of uncertainty about the future. 


\subsubsection{Singapore}

\subsubsection{Trade and Development Policies ${ }^{5}$}

The economy of Singapore, like that of Hong Kong, was for many years based on entrepott trade, specifically, the processing, repackaging, and re-exporting of the primary products of Southeast Asia to other areas and the re-exporting of imported industrial goods to other parts of Asia. Eollowing the attainment of self-government in 1959, the singapore government adopted an industrialization strategy that has passed through three stages: an import-substitution phase from 1960 to 1966; a labor-intensive, export-oriented phase from 1966 to 1970; and since 1970, a higher-technology, skill-intensive phase that is also export-oriented (Yue, 1980).

The first phase, in which tariffs and quotas were used to stimulate domestic manufacturing, was closely tied to the prospect of a Malaysian common market, including the former Malaya, Singapore, and the Borneo states of Sabah and Sarawak. Government officials thought that this market would be of sufficient size for singapore to become an efficient supplier of manufactured products, given temporary protection. But the political union of the four states lasted only from 1963 to 1965 , and with Singapore's withdrawal from the federation, the proposal for a Malaysian common market collapsed.

Although import protection was increased to ease the domestic adjustments related to the country's withdrawal from the 
federation, the development strategy shifted around 1966 to one of attracting foreign investment to expand exports of laborintensive manufactures. In addition to establishing new tax incentives to attract foreign investors, the government introduced restrictive labor legislation to restrain wage increases and maintain stable labor relations, restructured the educational system to provide more technical workers, and provided a wide range of facilities and services to industrialists. The outcome was a rapid decrease in unemployment, an increase in the share of domestic exports in total exports from $25 \%$ in 1965 to $38 \%$ in 1970 , and a marked acceleration of the growth rate.

As the upward pressure on wages increased due to the success of these measures, singapore shifted to a new development strategy in the early 1970s, emphasizing exports of skillintensive, higher-technology products. To stimulate the export of these products, the government provided equity and loan assistance to firms producing them, expanded training facilities and gave financial support to private-sector training activities, allocated funds for financing export bills below the prime rate, subsidized the insurance of export activities, and undertook extensive export-promotion programs. Beginning in 1969, most tariffs and quotas were reduced or abolished to enable exporting firms to obtain needed inputs at competitive world prices, and by the mid-1970s, Singapore's level of protection was very low.

The extent to which singapore has relied on foreign 
investment to increase its exports of manufactured goods is indicated by the fact that, in 1980, export sales by wholly foreign-owned firms constituted $72 \%$ of the economy's total exports of manufactured goods, export sales by joint ventures $21 \%$, and export sales by wholly locally-owned firms only $7 \%$. Another notable feature of the country's development policy is the high rate of domestic savings, achieved by compulsory retirement contributions by employers and employees. By 1978 the contribution rate reached $38.5 \%$ of wages and salaries and contributed $22 \%$ of total national savings. The government has used these funds to provide an infrastructure that is conducive to development.

\subsubsection{Trade Performance}

Unlike Hong Kong, singapore never relied on textiles and clothing as an important export product, as Table 9 shows. Its industrialization via the export route has been based mainly on oil refining and, to an increasing extent, on skill-intensive machinery and other manufactures. Industrialization has also expanded the market within singapore for high- skill, hightechnology products, as the changes in the country's import pattern indicate.

The United States has done very well in the Singapore market (Table 10), increasing its export share from 7\% in 1963 to $21 \%$ in 1984 - a performance that outdid the Japanese export share increase. The other ADCs also gained in market share, while the EC and, especially, the RRCs lost in relative terms. On the 
export side, the figures show that the shares of singapore's exports taken by both the United States and Japan rose between 1963 and 1984, the U.S. from $13 \%$ to $27 \%$ and Japan from $8 \%$ to $12 \%$. As would be expected from exchange rate developments, the increase in the share of exports going to the United States was especially large between 1980 and 1984. Shipments to other ADCs also increased in relative terms over the 21-year period. In contrast, the share of Singapore's exports received by the EC fell from $29 \%$ to $12 \%$ from 1963 to 1984 .

There is no alternative for Singapore, if it is to continue to raise its living standard, but to remain an open, exportoriented economy. At the same time, one can expect to see a continued shift in the composition of its exports toward higher labor-skill products, while importing high-technology goods as well as products where scale economies are important.

\subsubsection{Korea.}

\subsubsection{Trade and Development Policies ${ }^{6}$}

From 1945 to 1960 Korea followed an import-substitution development policy, using high protective tariffs, quantitative import restrictions, and a multiple exchange-rate system with a generally overvalued currency to stimulate domestic production for local markets. While growth was fairly impressive during the 1950s, it was largely induced by substantial U.S. aid following the Korean War; $74 \%$ of Korean investment was financed by foreign aid between 1953 and 1960. The growth rate began to decline in 
the late 1950s as the easy import-substitution opportunities were exploited and U.S. economic aid was reduced. The degree of inwardness of the economy at that time is indicated by the fact that exports of goods and services were only 3\% of GDP in 1960; by 1980 they had climbed to $36 \%$.

A significant shift in Korean development policy toward an outward-looking strategy occurred after the student revolution in 1960 and the military coup in 1961. The won was devalued and a unitary exchange-rate system established, the interest rate was permitted to rise to encourage domestic savings, and a stabilization program was implemented. A nunber of export incentives were introduced, including exemption from tariffs on imported inputs and capital equipment for use in export production, accelerated depreciation on capital facilities employed in export production, and a lowering of direct taxes on income earned from exporting. Exporters also had access to credit below the market-rate of interest, received preferential electricity and transportation rates, and were granted generous wastage allowances on imported inputs.

In the late 1970s another change in development policy occurred as the government, fearing that Korea was losing its competitive advantage in labor-intensive manufactures due to rising real wages, began to encourage the production of capitalintensive intermediate products. This policy shift was reversed in the early 1980s and priority again given to export expansion as the major engine of growth. 
The rate of growth that followed the shift in development strategy toward export promotion can only be described as phenomenal. Per capita incomes rose at an average annual rate of 7\% between 1960 and 1980. During the export-led industrial transformation, the share of manufactures in total exports increased from $14 \%$ in 1960 to $91 \%$ in 1983 (Table 11 ), and domestic savings as a fraction of GDP rose from $1 \%$ to $30 \%$ between 1960 and 1984 (Table 4).

A feature of Korean policy of considerable concern to the United states and other industrial countries with which Korea has a large export surplus is the continuing high level of protection in both the agricultural and industrial sectors that makes it difficult for foreign suppliers to sell in the Korean market.

\subsubsection{Trade Performance}

As Table 12 indicates, the United States export share in the Korean import market, after falling sharply from $49 \%$ to $31 \%$ between 1963 and 1970, increased slightly to $34 \%$ between 1970 and 1980 and then remained constant thereafter. Japan was the main gainer at U.S. expense between 1963 and 1970 with its share rising from $35 \%$ to $49 \%$, but this share had fallen back to about 41\% by 1984. Australia and New Zealand, Canada, and the RRCs have all gained steadily in market share throughout the 21-year period.

The distribution of Korean exports exhibits considerable volatility. Exports to the United States, for example, constituted $50 \%$ of all exports to the regions listed in the first 
column in 1970 , rising from $32 \%$ in 1963 , then dropping to $35 \%$ in 1980 , only to rise again to $46 \%$ during the period of dollar appreciation in the early 1980s. The share of exports sent to Japan shows a steady decline over the entire period. Exports to the European Community display an upward trend.

Because the country's poor endowment of natural resources and comparatively small size leave no alternative for achieving continued rapid growth but to retain the emphasis on exporting manufactured goods, Korea is likely to remain an outward-looking economy. Like singapore, it can be expected to move into higherskill, more capital-intensive export production, however. At the same time, with some prodding it should become a better market for high-technology goods and agricultural products.

The Republic of Korea's relations with North Korea are of major concern to the United States. Because of the perceived threat of aggression from the north, the United states still maintains military forces in south Korea and has a treaty commitment to the country's security. The U.S. government favors gradual reunification between North and South Korea but there seems little prospect for that in the short term. Yet, the prospect for reasonably peaceful relations between the two countries in the short term seems favorable.

\subsubsection{Taiwan}

3.1.4.1 Trade and Development Policies ${ }^{7}$

There was great political and economic turmoil in Taiwan in 
the period immediately after world War II. The end of fifty years of Japanese rule and thus the loss of the country's traditional export market was followed by the Communists' takeover of mainland China, the immigration of large numbers of Nationalists from the mainland and their assumption of power in Taiwan, and the loss of another important market in China.

The government's first response to the economic problems it faced was to undertake a land reform program in the agricultural sector and an import-substitution policy with high levels of protection for the manufacturing sector: The country's adjustment efforts were assisted by a substantial inflow of foreign aid, mainly from the United States. Between 1951 and 1959, $37 \%$ of total investment was financed by foreign aid.

Beginning in the late 1950s and into the early 1960s, the government introduced policies that changed Taiwan's development strategy from one of import substitution to one that emphasized the export of labor-intensive manufactures. The multiple exchange-rate system was abolished and the overvaluation of the country's currency corrected by a series of devaluations. Import controls were eased and tariffs reduced on many manufactured goods. (As in Korea, the Taiwanese government still highly protects some domestic industries with import controls and tariffs.) Investment by foreigners and local residents was encouraged by such measures as a five-year income tax holiday for certain new industrial establishments, a sharp reduction in the maximum business income tax, and tax exemption for undistributed 
profits retained for investment purposes. Exporting was also encouraged directly by rebating customs duties on imported inputs, permitting the deduction from taxable income of an amount equal to $2 \%$ of annual export earnings, and allowing a $10 \%$ tax deduction for manufacturing, mining, and handicraft firms that exported more than $50 \%$ of their output. In addition, some industries received direct export subsidies that were financed by levies on domestic sales. Low-interest loans and government assistance in the form of marketing, managerial, and technical services were also available for exporting activities. Beginning in the mid-1960s, the government also established duty-and taxfree export-processing zones.

\subsubsection{Trade Performance}

As in the Korean case, the post-World War II development policies of Taiwan transformed the country from an agricultural to an industrial economy within a comparatively short period. In the period 1952-54, industrial exports made up only $9 \%$ of total exports, but in 1970 the share of industrial exports in total exports was up to a level of $78 \%$ and by 1982 , to $88 \%$.

As Table 13 shows, changes in the country/regional distribution of Taiwan's imports between 1963 and 1984 are similar to those of Korea. The U.S. share of imports into Taiwan declined sharply from 43\% to $26 \%$ between 1963 and 1970, then increased to $33 \%$ in 1980 and remained constant thereafter. As in the Korean case, Japan's export share rose considerably between the first two years (from $35 \%$ to $52 \%$ ), then declined to $40 \%$ by 
1980 and remained there over the next four years. The EC's export share also rose over the entire period. In contrast to the Korean case, however, the export share of the other ADCs rose, while that of the RRCs fell.

Since the UNCTAD Trade Data tape does not contain exports from Taiwan for 1980 and 1984, the country/region composition of Taiwanese exports is only given for 1963 and 1970. These years do show the marked shift in the direction of Taiwanese exports toward the United States. From accounting for only $20 \%$ of these exports in 1963, the U.S. share had increased to $44 \%$ by 1970 . The Community's share rose slightly, but the most significant other shift between these years was the fall in Japan's share from $38 \%$ to $17 \%$.

Like Korea and Singapore, to achieve continued rapid growth, Taiwan has no alternative but to concentrate on exporting manufactured goods, but it can be expected to shift toward higher-skill-requiring, more capital-intensive products. As it is pressured to liberalize its own trade barriers, Taiwan should improve as a market for high-technology manufactures and agricultural products.

There is, of course, considerable uncertainty about the political future of Taiwan. In proposing unification, China has offered to make Taiwan a special administrative region, following the Hong Kong approach, and allow it to maintain its economic and social system. Thus far, however, no visible progress has been made toward reunification, despite Taiwan's increasing political 
isolation in the world. The official position of the U.S. government seems to be that a gradual and natural process of unification is best and that other countries should not intervene in this process.

\subsection{The Resource-Rich Countries}

\subsubsection{The Philippines}

\subsubsection{Trade and Development Policies}

The development policy of the Philippines since the late 1940s can be characterized as initially one of import substitution, then a series of modest and short-lived efforts to liberalize the trade and excliange-rate regimes. Exchange controls were first introduced in late 1949 as a consequence uf a balance-of-payments crisis caused immediately by the electionrelated easy credit and liberal spending policies of the goverment and more basically by the country's overvalued currency and pent-up demand for consumption goods. Rather than lifting the controls after the crisis passed, the government used them during the 1950 s to promote the development or dumestic manufacturing activities. As often happened in developing countries that follow this strategy, growth rates initially were quite high, but by the late 1950s, as the easy stage of import substitution had passed, they had fallen significantiy.

Devaluation, the elimination of most exchange controls, and the establishment of a unified exchange-rate system occurred in the early 1960s, but these changes were in response to charces of 
maladministration of the controls and pressures from traditional exporters rather than to a conscious decision to promote exports of manufactures. High tariffs still protected the manufacturing sector, although its growth rate fell even further in the early 1960s. An effort in the late 1960s to stimulate growth through credit and fiscal expansion led to a new balance-of-payments crisis and the re-introduction of exchange controls.

The 1970s began with the floating of the peso and the passage of legislation aimed directly at stimulating exports of non-traditional agricultural and manufactured goods. Firms exporting more than $50 \%$ of their output were exempt from sales or customs taxes on materials used in export production and permitted to deduct part of their export revenue from taxable income. The government also constructed the first exportprocessing zone. Partly in response to these measures but probably due more importantly to the $50 \%$ decline in real wage costs in manufacturing between 1969 and 1974, there was sustained growth in manufacturing exports until 1981 (Alburo and Shepherd, 1986). The share of manufacturing exports in total exports rose from $12 \%$ in 1970 to $44 \%$ in 1980 .

Further liberalization efforts were undertaken in the early $1980 \mathrm{~s}$, the most important of which was the reduction of tariffs under a new, more rational system of import protection, but the exchange crisis of 1983, related to the country's external debt problems, prevented the full implementation of the measures as exchange controls were introduced once again. Since 1984 the 
cutoff of foreign capital, the austerity measures the government was forced to adopt, and the political crisis in the country have brought about a decline in real GNP.

\subsubsection{Trade Performance}

The commodity distribution of the Philippines' exports and imports is given in Table 14. Primary product exports other than minerals have declined significantly between 1960 and 1983 as the share taken by manufactured goods rose from $4 \%$ to $50 \%$. Due to the greater importance of fuel imports, the share of imports of manufactured goods fell from 75\% to $65 \%$ between 1960 and 1983 .

The Philippines is another case where the U.S. share of the country's import market decreased significantly between 1963 and 1970, while Japan's share increased significantly (Table 15). The U.S. export share rose in the 1970 s and, despite the exchange rate developments, rose again in the 1980 s. The other major gainers were the ADCs, whose share of the Phillippines' imports went up from to $2 \%$ to $11 \%$ between 1963 and 1984. In contrast, the Japanese and EC export shares of the Philippine market fell in both of these periods.

The country/region distribution of Philippine exports shows a decreasing dependence on the United States as a trading partner. The share of the country's exports sent to the United States declined from $47 \%$ in 1963 to $27 \%$ by $1980 .{ }^{9}$ The share of exports taken by Japan rose somewhat from 1963 to 1980; the EC share remained about the same. The most important shift was the increase from $3 \%$ to $11 \%$ in the relative importance of the ADCs as 
an export market between these years. This may be related to the establishment of the Association of Southeast Asian Nations (ASEAN), since Singapore, an ADC, is an ASEAN member. Export share of the other ASEAN members, which are RRCs, remained roughly the same, however.

The economic history of the Philippines over the last forty years and the present political turmoil do not give reason to expect the country to shift its development strategy in the foreseeable future and focus on becoming an outward-looking exporter of manufactured goods. Periodic attempts to liberalize can be expected, but the conflicting economic and political pressures within the country seem likely to result in the same pattern of on-again, off-again government controls on trade and development that has been seen over the last forty years. Yet, because of the richness of its human and physical resources, the Philippines is likely to continue to grow at a respectable rate. U.S. concerns with the Philippines go beyond the historically close political and economic relationships between the two countries. Clark Air Force Base and Subic Bay Naval Base are the largest overseas American air and naval facilities, and they are generally regarded as vital to a U.S. military presence not only in the Pacific but also in the Indian Ocean and Persian Gulf. It would be a severe blow to U.S. military strategy if a Philippine government forced the United states to relinquish control over these bases. Since poor economic performance in the Philippine economy contributes to the possibility of such an 
outcome, the United states may wish to consider establishing closer economic ties with the Philippines, for example, by granting the country more favorable treatment under the Generalized System of Preferences or perhaps negotiating a free trade arrangement with the country.

\subsubsection{Malaysia}

\subsubsection{Trade and Development Policies ${ }^{10}$}

Peninsular Malaysia (the former Malaya) achieved political independence in 1957; Sabah and Sarawak became independent and part of Malaysia in 1963. Fortunately, Malaysia already had a per capita income that was considerably above the other three resource-rich countries. As in most developing countries, the Malaysian government began its industrialization endeavors with import substitution fostered by moderate levels of protection and generous fiscal incentives, such as were provided in the Pioneer Industries Ordinance in 1958 and the broader Investment Incentive Act in 1968. In the late 1960s and early 1970s, a deliberate effort was made to promote exports. This included permitting a double deduction from taxable income for export expenses and a further tax deduction based on Malaysian raw material and wage costs. Free-trade and export-processing zones, in which firms can freely import materials and capital goods used in export production, were also established in various parts of the country. Furthermore, the government provided low-cost export insurance, helped to keep shipping rates low, and engaged in the 
promotion of Malaysian exports throughout the world.

The country's development efforts have been successful in achieving an impressive degree of diversification of both primary-product and manufacturing activities. For example, palm oil and timber production has increased to the point that these sectors are now as important as the rubber and tin industries as earners of foreign exchange. Impressive processing activities have been established in the palm oil and rubber sectors. The oil and natural gas industries have also become major exportearning industries. Textiles and apparel, electrical machinery, and, especially, electronics products have become important export items as well. As can be seen from Table 16, exports of manufactured products increased from $6 \%$ of total exports in 1960 to $22 \%$ in 1983 .

\subsubsection{Trade Performance}

The Malaysian import figures for 1963 seem unreliable, due perhaps to its political union with singapore in that year. Subsequent data show a steady increase in the share of the Malaysian import market captured by the United states, this share rising from $11 \%$ in 1970 to $16 \%$ by 1984 (Table 17). Japan's share increased significantly between these years, from $4 \%$ to $25 \%$, while the EC's share decreased significantly. Import trade with the ADCs also rose appreciably but dropped with the other RRCs.

The country/region distribution of Malaysian exports indicates that the United States gradually increased its share between 1963 and $1980 .{ }^{11}$ Shipments to Japan, the ADCs, and the 
other RRCs remained about the same over the time period; those to the EC fell in relative importance.

Malaysia has been successful in achieving an export-oriented industrialization strategy that is based on processing its abundant natural resources and on utilizing its abundant supply of low-cost labor. There would seem to be no major reasons why this pattern will not continue, at least in the medium term.

\subsubsection{Thailand}

\subsubsection{Trade and Development Policies ${ }^{2}$}

The modern industrialization efforts of the government of Thailand can be said to have begun with the establishment in 1959 of the Board of Investment, set up to promote domestic investment with the use of tax incentives, and a new, mildly protective customs schedule was put into effect in 1960. The government also influenced industrial expansion by means of entry controls and the use of preferential credit arrangements. The net effect was a development policy that to some extent favored manufacturing industries producing for the domestic market.

With the passage of the Export Promotion Act in 1972, greater attention was given to the promotion of manufactured exports. Its provisions included exemption from paying import duties on imported materials used in production for export, the exemption from business taxes on export-producing activities, and a Bank of Thailand discount facility at below-market rates for short-term export loans made by commercial banks. Since 1972 
exporters are also eligible for a $20 \%$ rebate on electricity charges incurred in export production. The Department of Commerce began export-promoting activities in 1975.

Beginning in 1974, as the sharp increase in the price of oil caused a deterioration in the country's balance of payments, there was an increase in industrial import protection. Nominal protection on import-competing manufactured goods increased from 35\% to 50\% between 1974 and 1978 (World Bank, 1980). Greater increases in business taxes on imports than on comparable domestic products, the imposition of import surcharges on certain products, and the increased use of import controls were other policies favoring import-substituting activities. The debt crisis of the early 1980 s and a sharp deterioration in Thailand's terms of trade brought about further import restrictions.

\subsubsection{Trade Performance}

Despite the somewhat contradictory nature of Thailand's recent development policies, export growth has been very high in the last decade (Table 2), with exports of textiles and apparel, machinery and equipment, and other manufactures continuing to make up an increasing share of the country's total exports (Table 18).

As in a number of the other APR countries, the U.S. share of Thailand's imports from its major trading partners decreased between 1963 and 1970 as Japan's share increased (Table 19). In the Thai case, however, these share changes were not as great as in the other cases. The pattern of a U.S. share gain and a 
Japanese 10ss in the 1970s, as the dollar depreciated, and the reverse of these changes in the 1980s, as the dollar appreciated, also took place in Thailand. The EC share in Thailand's imports fell steadily throughout the period. The other important change in export shares was the increase in the $\mathrm{ADCs}$ share from $11 \%$ in 1963 to $22 \%$ in 1984 . The share of the other RRCs in exports to Thailand remained about the same over the period.

The share of Thailand's exports absorbed by the United States rose significantly from 10\% to $22 \%$ between 1963 and 1984 . Shipments to the EC also increased between these years but only from 23\% to 27\%. Japan's share fell after 1970 from $30 \%$ to $17 \%$. Interestingly, Thai exports to other RRCs and the ADCs diminished in relative importance over the entire period.

The Thai government's policy of modest intervention in the market economy seems likely to continue into the foreseeable future and to result in high growth rates and a growing degree of export-oriented industrial diversification.

\subsubsection{Indonesia}

\subsubsection{Trade and Development Policies ${ }^{13}$}

Indonesia has been the least successful of the resource-rich countries in shifting from an inward-looking policy that protects domestic producers of manufactured products from foreign competition to a strategy of promoting exports of manufactures. The $8 \%$ share of manufactures in total exports in 1983 (Table 3) is much lower than that for the other three RRCs. The unusual 
richness of its resources and especially its ability to take advantage in export markets of the sharp oil price increase in the 1970s may in part be responsible for this low manufacturing share by reducing the balance-of-payments pressures for the expansion of manufactured exports.

Four separate periods can be distinguished since Indonesia achieved its independence in 1949: the period of constitutional democracy (1950-57); the "Guided Democracy" of 1958-1965; the liberalization of the "New Order" (1966-1971); and developments up to the present after the period of liberalization (Pitt, 1985). The first period saw sporadic attempts to dismantle the elaborate system of foreign exchange controls and import quotas that had existed under Dutch rule. But lobbying pressures on the government to grant preferential import privileges to the new class of indigenous importers and to monopolistic organizations of domestic industrial firms formed to import a common raw material tended to undermine these liberalization efforts.

The second period, 1958-1965, was marked by President Sukarno's implementation of his concept of "guided democracy" under which there was an aversion to free markets and foreign capital. The traditional Dutch trading houses were nationalized so that by 1959 only 20\% of the import trade remained in private hands. The government allocated all foreign exchange and, in doing so, favored inward-oriented state enterprises. Moreover, the government's policy of allocating raw materials on the basis of a firm's existing productive capacity encouraged the expansion 
of capacity, though this capacity was under-utilized; in 1965 manufacturing as a whole operated at only between $20 \%$ and $30 \%$ of capacity.

The period 1966-71 saw sweeping liberalization in Indonesia, beginning with a scheme to encourage exports that permitted exporters to sell a portion of their foreign exchange earnings at free-market prices. The government ended the direct allocation of foreign exchange to manufacturing firms and importers were permitted to buy almost any good they wished. Subsidies and preferential credit rates to state enterprises were cut sharply. Another important change was the enactment of a law to encourage foreign investment by exempting firms that undertook priority investments from taxes on as much as $60 \%$ of their profits for up to six. years. A unified exchange-rate system was established in 1970.

In the period immediately after the liberalization phase, the new government shifted back toward import substitution with the increased use of quantitative import controls, including the banning of imports of many consumer goods, an increase in tariffs, and the introduction of numerous regulations covering investment activities. In 1978, however, the currency was devalued and an export certificate scheme was introduced that tended to subsidize exports of manufactured goods. This led to a significant percentage increase in such exports, though starting from a very low level. Nevertheless, the government's policies are still biased toward capital-intensive, import-substituting 
activities and include cumbersome regulations that discourage exports of labor-intensive manufactures.

\subsubsection{Trade Performance}

Unlike in the other countries analyzed, the structure of Indonesian production has not shifted significantly toward export-oriented manufacturing. Only $7 \%$ of the country's exports were manufactured goods in 1983 (Table 20), while the share of fuels, minerals, and metals in exports rose from $33 \%$ to $80 \%$ between 1960 and 1983 .

The country/region composition of Indonesian imports (Table 21) shows a rise in shares from both the United States and Japan between 1963 and 1970 and a decline in the export shares of the ADCs, the RRCs, and the EC. In the 1970s the U.S share fell and Japan's increased, while in the 1980s their shares remained unchanged. In contrast, the share of imports from the Community increased in the 1980s. Imports from the ADCs dropped sharply from $19 \%$ to $5 \%$ between 1963 and 1970 but remained roughly constant thereafter.

Indonesian exports to both the United States and Japan rose significantly in the 1970s, while exports to the EC and the ADCs fell appreciably during this period. In the period of the 1980s covered in Table 21, the percentage distribution of the destination of Indonesian exports remained roughly the same.

As in the Philippines, there do not seem to be any strong reasons to expect that Indonesia will change its development strategy from that of recent years. Strong vested interests have 
been created that favor an inward-looking industrialization strategy, and they are likely to continue to prevail in the political decision-making process determining development policy into the foreseeable future.

\subsection{China}

\subsubsection{Trade and Development Policies ${ }^{4}$}

Undoubtedly, the developing country in the APR whose policies are of greatest potential significance to the United states and other competitors in the region is China. The modernization reforms initiated in the late 1970s could eventually transform the Chinese economy into both a major competitor and market in the area and the world. But the possibility of a return to Maoist economic policies, involving autarky and a de-emphasis on the acquisition of Western technology, cannot be ruled out.

China's current trade policies are aimed at increasing exports in order to pay for the capital equipment, intermediate inputs, and advanced technology needed for industrial and agricultural modernization. One means of stimulating exports has been the establishment of Special Export Zones in which Western know-how, managerial skills, and capital can be combined in joint ventures with low-wage Chinese labor. As Table 22 indicates, the share of exports of manufactures in total exports equaled $57 \%$ in 1983, with textiles and clothing being the most important export category. Among the country's primary product exports, 
crude petroleum and petroleum products have become increasingly important.

Encouraged by government policy, foreign investment in China exceeded $\$ 3.5$ billion by 1985, but firms doing business in China face many difficulties, including arbitrary tax and tariff charges, inadequate supplies of skilled labor, poor transportation and communication facilities, and the resistance of vested interests to the economic reforms.

\subsubsection{Trade Performance}

After U.S. trade with China opened up; the United States quickly became an important supplier, furnishing by 1980 about a quarter of China's imports from its major market-oriented trading partners (Table 23). The U.S. share dropped to $18 \%$ by 1984 , perhaps reflecting the overvalued dollar. Japan's share rose from $11 \%$ in 1963 to $43 \%$ by 1984, and the ADCs became more important as exporters to China over the period, whereas the shares of exports supplied by the EC and Australia and New Zealand declined between these years.

Chinese export figures are only available for 1984 on the UNCTAD Data Tape. The $42 \%$ share going to Hong Kong indicates the importance of that colony as an entrepot for China. Japan is the next largest recipient of Chinese goods at $27 \%$ and the United states and the European Community each absorbed about $12 \%$ in 1984 .

It seems much too early to predict, even in the medium term, what China's future role in the world trading and foreign 
investment system will be.

4. THE COMPETITIVE PEREORMANCE OF THE UNITED STATES AND ITS MAJOR COMPETITORS IN THE APR MARKET

In the preceding section the major country/region distribution of the imports and exports of each of the nine developing countries in the Asian Pacific Rim was examined. As is apparent from this analysis, no single pattern emerges as to how well the United States has competed in the area. In three markets - Singapore, Malaysia, and China, the share of U.S. exports in total exports from the countries major trading partners was greater in 1984 than in 1963.' In four countriesthe Philippines, Hong Kong, Indonesia, and Thailand, this export share declined but by six percentage points or less. In two countries, Korea and Taiwan, the U.S. share of exports dropped by more than ten percentage points over the period. Interestingly, except for Hong Kong, Korea and Taiwan ship a larger proportion of their exports to the United States than any other countries in the group.

In only two countries, Hong Kong and China, is there a more than 5\% decline in the U.S. export share between 1980 and 1984, when the dollar appreciated significantly. Indeed, the U.S. export share rose between these years in the Philippines, Singapore, and Malaysia. During 1970, however, when the dollar depreciated against the major currencies, the U.S. share of the export market increased in Korea, Taiwan, Thailand, Malaysia, Singapore, and the Philippines. Furthermore, in all of these 
countries the share of exports supplied by the United States was higher in 1984 than in 1970. In four countries - Thailand, Korea, the Philippines, and Taiwan, the U.S. competitive position worsened between 1963 and 1970. (Data are not available for these two years for China and Malaysia.)

Table 24 indicates the importance of developing countries of the APR as an export market for the United States. (Also see Naya, 1986.) The shares of total U.S. exports going to the ADCs, the RRCs, and China all increased between 1968 and 1982, the combined share for all three rising from $6.5 \%$ in 1968 to $13.1 \%$ in 1982. If one adds Japan's share of U.S. exports to these figures, which increased between 1968 and 1982 from $8.5 \%$ to 9.9\%, the combined exports of the United states to the major developing and developed countries of the APR constituted $15.0 \%$ of all U.S. exports in 1968 and $23.0 \%$ in 1982. There is no doubt that the Asian Pacific Rim is becoming a major area of export interest to the United States.

Table 25 examines the success in trade of the United states relative to its major competitors in the import markets of developing countries of the APR, not on an individual-country basis but in the ADCs and the RRCs as groups of countries, and in China. The competitive record of the United States is shown to be a mixed one. The U.S. export share in the import market of the ADCs in the area remained at around 20\% between 1963 and 1984 - $20 \%$ in 1963, $18 \%$ in 1970, and $21 \%$ in both 1980 and 1984 , whereas its share of the goods exported by the major suppliers to 
the four RRCs dropped steadily from $24 \%$ in 1963 to $16 \%$ in $1984 .{ }^{15}$ In contrast, after U.S. trade with China was opened, the U.S. share of the Chinese market rose to $27 \%$ by 1980 , then declined to $18 \%$ in 1984 .

For the region as a whole, the trend in the U.S. export share was slightly upward, moving down from $21.6 \%$ in 1963 to $19.0 \%$ in 1970 but then rising to $23.5 \%$ in 1980 and remaining almost unchanged at $23.2 \%$ in 1984, despite the sharp appreciation of the dollar. The significance of this upward trend in export performance in the APR market can be appreciated by noting that the U.S. share in world exports declined between 1963 and 1984, falling from $14.6 \%$ in 1963 to $13.6 \%$ in 1970 and $11.0 \%$ in 1980 and then rising slightly to $11.2 \%$ in 1984.

The most successful competitor in the APR market was Japan. Its shares of total exports to the ADCs, the RRCs, and China from the countries listed in the first column of Table 25 rose for all three between 1963 and 1984: By 1984 Japan was their largest supplier, supplying $30 \%$ of the ADCs' import market, $26 \%$ of the RRCs $^{\circ}$ import market, and $43 \%$ of China's imports from the countries listed. The main loser in competition for sales in these markets was the European Community; its export shares declined steadily in all three parts of the APR market over the 21-year period.

An important change in the markets of developing countries that is only beginning to be appreciated (e.g., see Ahmad, 1985) is that the more advanced developing countries are beginning to 
be important suppliers of manufactured goods to other developing countries. This is clearly occurring in the APR market. As Table 25 shows, the export share of the ADCs in their own import market increased from $8 \%$ in 1963 to $12 \%$ by 1984 , while their export share in the RRCs ' market rose from $1 \%$ to $10 \%$ between these years. The less industrially advanced RRCs did not participate in this trend, however; their shares to the ADCs and to other RRCs declined over the period.

Another aspect of the growing importance of the market for international goods in the developing countries of the APR is that total exports to these countries by the United states, Canada, Japan, Australia, New Zealand, the European Community, as well as by the countries of the region to each other, amounted to $2.97 \%$ of world exports in $1963,3.56 \%$ in $1970,4.74 \%$ in 1980 , and $5.85 \%$ in 1984 .

Changes in the commodity composition of U.S. exports to the ADCs, the RRCs, and China between 1968 and 1982 are indicated in the first part of Table 26. The comparative advantage of the United states in agricultural products and high-technology goods is evident. As would be expected, agricultural imports are more important for the resource-scarce ADCs and China than for the RRCs. For both the ADCs and the RRCs, exports of machinery have grown significantly in relative importance over the period, from 21\% for the ADCs in 1963 to $34 \%$ in 1982 and from $30 \%$ to $49 \%$ for the RRCs between these years. The relative decline in exports to China of machinery between 1975 and 1982 may reflect special 
circumstances. Another commodity class that gained somewhat in relative importance over the period is chemicals, whereas transportation equipment declined.

Eurther insight into which categories of goods the competitors in the APR market have been successful in exporting can be gained by utilizing Krause's (1982) breakdown of goods into four groups: natural resource-intensive, unskilled laborintensive, technology-intensive, and human capital-intensive. Table 25 divides the exports to the APR of the United States and its competitors into these four categories. As would be predicted under the factor-proportion theory of international trade, the commodity groups in which the United States has the largest market share are natural resource-intensive and technology-intensive. In trade with the ADCs, the U.S. export share increased modestly over the 1963-1984 period for both types of goods. For the RRCs, the U.S. export share declined for natural resource products - a not-unexpected result - and also for technology-intensive products, though less than in the other product categories. U.S. performance in the import market of the APR countries declined, as expected, for labor-intensive products and also, rather surprisingly, for human capital-intensive products. As Table 27 indicates, the fastest growing category of exports to ADCs and RRCs was, except for the 1980-84 period, technology-intensive goods. The United States is in the fortunate position of specializing in commodities for which market demand is growing rapidly. 
Another picture of the nature of U.S. exports, utilizing the U.S. Department of Commerce (1976) breakdown of all goods into those that are technology-intensive and non-technology-intensive, is presented in Table 28. The analytical assumption behind this division is, of course, that temporary differences among countries in developing and introducing new technological knowledge are the basis for differences in the commodity composition of trade. Though not always explicit, the ability to create new technology and undertake innovation depends, in turn, on there being high levels of research and managerial skills. The table shows that over the 1968-1982 period the United states has shifted the composition of its exports to every country or region toward high-tech goods. Imports from every region have moved in this direction, but the percentage by which technology-intensive exports to the world by the United states exceed technologyintensive imports was still about the same in 1982 as in 1968 .

Consistent with the factor-proportion theory, Table 25 shows that the main U.S. competitor in the APR, Japan, gained marketshare position over the period in the ADCs, the RRCs, and China in technology-intensive and human capital-intensive goods, while it lost in the labor-intensive category. The EC lost in every category between 1963 and 1984, whereas the ADCs gained in export shares within their own market in every category, registering an especially impressive gain in the high-technology group.

A technique developed by Hilton (1983) provides still another means of revealing the comparative-cost position of the 
United States vis-à-vis the countries of the Asian Pacific Rim. It involves regressing the ratio of U.S. exports to U.S. imports to a country by commodity on the cost shares of capital, unskilled labor, skilled labor, land, and other natural resources in the individual commodities. The coefficients on the various factor shares are a measure of the differences in relative factor-prices between the United States and the other country. If, for example, the coefficient on a particular factor is positive, this implies that the relative price of the factor is lower in the United States than in the other country. A negative sign means that the factor is relatively cheaper in the other country and, thus, that the other country has a comparative advantage in producing goods in which that factor constitutes a relatively large proportion of production costs.

The results of regressing bilateral export/import ratios for the United States and the countries of the APR for (in most cases) over. 200 commodities on a five-fold division of factor shares for these commodities are presented in Table 29 . For all the countries listed, the United States has a relative factorprice advantage in skilled labor and a disadvantage in unskilled labor. Eurthermore, for all countries except Indonesia (and that coefficient is not significant at the $10 \%$ level or better), the United states has a comparative factor-price advantage in physical capital. As expected, the United States has a comparative advantage in land-intensive and natural resourceintensive products vis-à-vis Hong Kong, Taiwan, and Korea. The 
land coefficient has the wrong (but not significant) sign for Singapore, while the negative sign on the natural resource coefficient reflects Singapore exports of refined petroleum.

The four resource-rich countries, Malaysia, Thailand, the Philippines, and Indonesia, all have a factor-price advantage in both land and natural resources relative to the United states. The U.S. trade pattern with Japan reveals that the United States has a relative factor-price advantage in natural resources, land, and capital and a disadvantage in unskilled labor. Interestingly, though not quite significant at the $10 \%$ level, the coefficient on skilled labor indicates that Japan has a comparative price advantage in this factor, too.

5. EXPORT PEREORMANCE OF THE DEVELOPING COUNTRIES OF THE APR

Although this paper is primarily concerned with the performance of the United states and its competitors in the APR market, data has also been collected on the performance of the developing countries of the region in the markets of the United States, Canada, Japan, Australia and New Zealand, the European Community, and in the region itself. Analysis of the trade of the individual countries in section 3 revealed that every country except the Philippines shipped a larger proportion of its exports to the United States at the end of the period covered (usually 1984) than in the beginning (usually 1963). In most cases, the increase was very significant. In contrast, the share of exports from Korea, Taiwan, the Philippines, and Thailand to Japan 
declined over the period, while the export shares from Hong Kong and Malaysia to Japan remained unchanged. Only the export shares of Indonesia and Singapore to Japan rose. The share of exports taken by the EC declined for Malaysia, Indonesia, and Hong Kong, remained about the same for Singapore, Taiwan, and the Philippines, and increased for Korea and Thailand.

The relative position of the APR countries as sources of imports for the United States is given in Table 24. The developing countries of the region supplied $6.5 \%$ of all U.S. imports in $1968,10.7 \%$ in 1968 , and $14.7 \%$ in 1982 . The share of the ADCs in these figures rose from $53 \%$ in 1975 to $63 \%$ in 1982 . Adding Japan's import share to the shares of the developing countries brings the figures to $19.1 \%, 22.7 \%$, and $30.5 \%$, respectively, in the three years.

The U.S. export share to the developing countries of the APR rose 6.5 percentage points between 1968 and 1982 , while the U.S. import share from these countries increased 8.2 percentage points. The U.S. export share to Japan rose 1.2 percentage points, and the U.S. import share from Japan rose 3.2 percentage points in the same period.

The most important category of imports into the United States from the ADCs and China is textiles and apparel (Table 26). The proportion that these goods make up of total U.S. imports from the ADCs is declining, but textiles and apparel have become more important in U.S. imports from China. Oil and gas was the main import from the RRCs in the early part of the period 
covered, but by 1982 the 30\% share for this category was matched by a $30 \%$ share for imports of electrical and electronic machinery. Electrical and electronic products are also an important category of imports from the ADCC.

The change in composition of U.S. imports from the APR developing countries toward more complex products such as electrical and electronic machinery is also apparent from Table 28, which divides all imports into technology-intensive and nontechnology-intensive goods. As this table indicates, imports from all the countries or regions listed are becoming more technology-intensive.

\section{DIRECT INVESTMENT IN THE APR COUNTRIES}

Achieving a market position abroad by means of direct foreign investment., in addition to exporting goods, has become an increasingly important element in corporate stategy over the last 25 years. Table 31 indicates the extent to which U.S. and Japanese companies have pursued this strategy in the APR countries. Although total Japanese direct investment in the ADCs and RRCs combined is nearly $\$ 2$ billion more than U.S. investment, American investment in the ADCs is greater than Japan's, $\$ 4.2$ billion versus $\$ 3.5$ billion. In view of Japan's lack of natural resources, it is to be expected that Japanese direct investment in the RRCs is greater. Japan's investment in oil-rich Indonesia alone amounted to $46 \%$ of its total investment in the APR. Korea and Hong Kong were Japan's next most important direct investment 
markets. Hong Kong followed by Indonesia and the Philippines were the most important U.S. investment markets in the area.

Tables 32 and 33 provide additional information on U.S. direct investment. Table 32 indicates the share of total world U.S. direct investment received by individual APR countries and industries in these countries. U.S. direct investment in the APR is a small but rapidly growing proportion of total U.S. direct investment, its share of total U.S. direct investment rising from $3.6 \%$ in 1977 to $6.7 \%$ in 1984 . The shares in each country except the Philippines increased between these years. The most important APR countries for U.S. direct investment in 1977 (and, as seen in Table 31, also in 1980) were, in order of relative importance, Hong Kong, Indonesia, and the Philippines. In 1984 the ranking was Indonesia, Hong Kong, and Philippines/Malaysia.

U.S. investment in the region is focussed more on the primary and service sectors than on manufacturing, which absorbed only $3.6 \%$ of total U.S. manufacturing investment abroad in 1984 , whereas the shares were $8.7 \%$ for petroleum, $10.7 \%$ for banking, $6.4 \%$ for trade, and $4.7 \%$ for banking. Indonesia and Malaysia were the major countries in which U.S. petroleum investments were made. U.S. investment in service activities went mainly into Hong Kong, Singapore, and the Philippines.

Table 33 shows the industry distribution of U.S. direct investment in each country in 1977 and 1984. Except for Indonesia, there has been a relative shift away from investment in primary-product sectors and toward manufacturing and/or 
service activities. In Korea and Taiwan the relative importance of U.S. manufacturing investment declined between 1977 and 1984, perhaps reflecting their advancing industrialization. The share of investment in manufacturing increased significantly in Malaysia and Singapore and remained about the same in Hong Kong and the Philippines. Service activities investment increased in relative terms in Korea, Hong Kong, and the Philippines.

\section{CONCLUSIONS}

A number of conclusions can be drawn from this analysis of the economic performance of the United States and its competitors in the developing countries of the Asian Pacific Rim, defined to include Singapore, Hong Kong, Taiwan, Korea, the Philippines, Malaysia, Thailand, Indonesia, and China. First, and perhaps most important, is that the APR is a rapidly growing, though still small, international market for goods and services and foreign direct investment. Exports to the countries of the region by their major trading partners, defined as the United States, Canada, Japan, the European Community, Australia and New Zealand, and the APR countries themselves, amounted to $3.0 \%$ of total world exports in 1963 and $5.8 \%$ in 1984. The area also has become relatively more important as a market for U.S. exporters, the share of total U.S. exports going to the APR rising from $6.5 \%$ in 1968 to $13.1 \%$ in 1982. If Japan's share of U.S. exports is added to these figures, the share of U.S. exports taken by the developed and developing countries of the APR moved from $15.0 \%$ in 
1968 to $23.0 \%$ in 1982 .

The United States has performed quite well in competing with the other major trading partners (defined as in the preceding paragraph) of the APR countries. The U.S. export share of this market rose from $21.6 \%$ in 1963 to $23.5 \%$ in 1980 and remained near that level in 1984, despite the appreciation of the dollar relative to the currencies of Japan, the countries of the European Community, and other U.S. competitors in the region after 1980. Within the region, the U.S. gained slightly in market share in the markets of the ADCs (defined as Hong Kong, Korea, Taiwan, and Singapore), moving from $20 \%$ in 1963 to $21 \%$ in 1984, but lost in the RRCs (defined as the Philippines, Malaysia, Thailand, and Indonesia), falling from a 24\% share in 1963 to a $16 \%$ share in 1984. In the Chinese market the United States had no market position in 1963, but by 1984 the U.S.share of China's imports from its major trading partners was $18 \%$.

The major competitor of the United States in the region is Japan. In 1984 Japan's share of the ADCs' market was 30\%, as compared to the U.S. share of $21 \%$, and the Japanese share of the RRCs market was $26 \%$ compared to the U.S. share of $16 \%$ in that year. Japan supplied $43 \%$ of China's imports from its major trading partners in 1984, whereas the United States supplied only $18 \%$.

Japan has also been the most successful competitor over the period in terms of gains in market shares. In 1963, for example, the U.S. and Japanese shares of imports into the ADCs and RRCs 
from their main trading partners were about the same, whereas, as noted above, in 1984 Japanese market shares exceeded the U.S. shares by about ten percentage points. The biggest loser in the competition for market shares has been the European Community. The EC's shares of the market for foreign goods in the ADCs and RRCs were only slightly below those of Japan and the United States in 1963, but they are now below the ADCs as suppliers to the ADCs themselves and to the RRCs. The rapid growth in the market shares achieved by the ADCs is one of the most important developments in the area. It must be recognized that these countries are beginning to supply an increasing proportion of the market for manufactured goods in the APR. China, too, is now taking an appreciable part of this market.

The various methods used to reveal the comparative-advantage position of the United States in the region indicate, as would be predicted from the factor-proportion theory of international trade, that the United States has a competitive advantage in commodities utilizing relatively large capital and skilled labor factor shares. Furthermore, in the resource-scarce ADCs, the United states has a comparative advantage in land-intensive and other natural resource-intensive commodities. The United States tends to be at a disadvantage in producing labor-intensive goods in the entire market and in land-intensive and natural resourceintensive goods in the RRCs.

One observes the results of these basic factor conditions in the commodity composition of U.S. exports to the region, that 
tend to be concentrated in natural resource-intensive goods, such as agricultural products, and in technology-intensive goods, that require relatively high professional and managerial skills to market successfully. It is in these that the United states is competing most successfully against its export rivals in the APR market. One would expect this pattern to continue, though it must be recognized that not only Japan but the ADCs and RRCs are shifting into the high-tech area. The United states must continually upgrade its level of high-tech products to maintain its market positions in the APR market and other world markets.

Market opportunities for the United States depend on economic and political conditions in the countries of the region as well as on U.S. competitive abilities. It seems that the present APR governments will continue to pursue export-oriented economic policies. There is, however, some political uncertainty stemming from outside pressures in Hong Kong and Taiwan, and from both outside and inside pressures in Korea. It is conceivable but unlikely that these pressures could bring government changes that would reduce market opportunities in these countries. Even with the present governments in Korea and Taiwan, the United States needs to apply pressure for the removal of their import barriers.

There is considerable political uncertainty in another important market for U.S. goods, the Philippines. One would expect economic policies to continue as they have with alternate cycles of liberalization and control, resulting in a moderate rate of growth. But there is also the possibility of a political 
shift resulting not only in more inward-looking economic policies but in the removal of U.S. military bases from the country. In Indonesia there are also strong political interests favoring import-substitution over export-promotion policies. Unlike the ADCs, resource-rich countries like Indonesia and the Philippines are not forced to promote exports of manufactures to produce a politically acceptable growth rate. Thailand and Malaysia are not only rich in resources but have adopted policies to utilize their abundant supplies of unskilled labor to produce manufactured goods for export. They should continue to do well, but like the other countries must be pressured to open their own markets to a greater extent.

While this paper has been mainly concerned with the export opportunities of the United states and others in the APR market, data have also been collected on the performance of the APR countries in world export markets. The picture that emerges is a familiar one. The developing countries of the APR have sent an increasing share of their exports to the United States, in many cases a significantly larger share. In 1984 the U.S. trade with the RRCs was roughly in balance, but the U.S. incurred a merchandise deficit of over $\$ 6$ billion with the ADCs. The shares sent to Japan have generally declined or, in a few cases, remained about the same. For the EC the share changes are mixed - some rising, some staying the same, and others declining.

Textiles and apparel are the most important category of imports from the ADCs and China, but products requiring higher 
skills, particularly electrical machinery and electronic products, are becoming more significant. Oil and gas have long dominated the RRCs' pattern of exports to the United States, but in recent years electrical and electronic products have challenged their position as the most important export category. clearly, the APR countries are increasing the degree of complexity of their export product mix.

The 1980 volume of direct investment by the United states in the ADCs was greater than Japan's, but Japanese direct investment in the entire region was greater than that of the United states. The United States is, however, increasing the share of its total investment going to the region, though this share is still quite small, growing from $3.6 \%$ in 1977 to $6.7 \%$ in 1984 . Oil and gas and service activities, such as banking and trade, are the sectors in the APR that receive the largest share of world investment. Services and manufacturing are the sectors in which investment in the developing countries of the Asian Pacific Rim is growing most rapidly. 
1. Henceforth, in this paper "APR" will refer only to the developing countries of the Asian Pacific Rim; Japan is not included.

2. The high proportion of primary product exports for singapore reflects the large imports of crude petroleum and re-exports of refined petroleum products.

3. Hong Kong's rate of population increase is relatively high because of immigration.

4. The account of Hong Kong's trade and development policies is based on Lin and Mok (1985), Chen (1984), Lin and Ho (1981), and Cooper (1986).

5. The account of Singapore's trade and development policies is based on Yue (1980, 1985), Wong (1981), Roberts (1985), and Cooper (1986).

6. The account of Korea's trade and development policies is based on Frank (1975), Nam (1981), Hong (1977), Balassa (1986), and Cooper (1986).

7. The account of Taiwan's trade and development policies is based on Liang and Liang (1981), Kuo and Fei (1986), Ranis and Schive (1986), Balassa (1981), and Cooper (1986). 
8. The account of the Philippines' trade and development policies is based on Bautista (1980), Baldwin (1975), Alburo and Shepherd (1986), and Niksch (1986).

9. Philippine export data for 1984 are not yet on the UNCTAD Trade Data tape.

10. The account of Malaysia's trade and development policies is based on Ariff (1980), Lim (1984), and Niksch (1986).

11. There are no export figures yet on the UNCTAD Trade Data tape for 1984 .

12. The account of Thailand's trade and development policies is based on Akrasansee (1977, 1980), World Bank (1980), Ajanant (1984), and Niksch (1986).

13. The account of Indonesia's trade and development policies is based on Rosendale (1977), Anwar (1980), World Bank (1981), and Pitt (1985).

14. The account of China's trade and development policies is based on Hardt and Boone (1986) and Ahearn (1986).

15. In interpreting the percentages in the table, note that the 1980 and 1984 figures do not include trade data on Taiwan. 


\section{REEERENCES}

Ahearn, Raymond J. (1986), "Asian-Pacific Economic Development: The Long-Term Historical Perspective (1960-Present)." In Economic Changes in the Asian Pacific Rim: Policy Prospectus. Washington, D.C.: Congressional Research Service.

Ahmad, Jaleel (1985), "South-South Trade in Manufactures: Implications for the North." Paper presented at conference, International Trade and Exchange Rates in the Late Eighties, Facultes Universitaires Notre-Dame De La Paix, Namur, Belgium, June 6-8, 1985.

Ajanant, Juanjai (1984), "Trade Patterns and Trends of Thailand." Paper presented at conference, Global Implications of the Trade Patterns of East and Southeast Asia, Kuala Lumpur, January 4-6, 1984.

Akrasanee, Narongchai (1977), "Industrialization and Trade Policies and Employment Effects in Thailand." In Narongchai Akrasanee, Seiji Naya, and Vinyr Vichit-Vadakan (eds.), Trade and Employment in Asia and the Pacific. Manila: Council for Asian Manpower Studies.

(1980), "Economic Development of Thailand and ASEAN Economic Cooperation, with special Reference to Commodity Problems." In Ross Garnaut (ed.), ASEAN in a Changing Pacific and World Economy. Canberra: Australian National University Press. 
Alburo, Florian and Geoffrey Shepherd (1986), Trade Liberalization: The Philippine Experience. Draft study prepared for a World Bank research project.

Anwar, M. Arsjad (1980), "Trade strategies and Industrial Development in Indonesia." In Ross Garnaut (ed.), ASEAN in a Changing Pacific and World Economy. Canberra: Australian National University Press.

Ariff, Mohamed (1980), "Malaysia's Trade and Industrialization Strategy: With Special Reference to ASEAN Industrial Cooperation." In Ross Garnaut (ed.), ASEAN in a Changing Pacific and World Economy. Canberra: Australian National University Press.

Balassa, Bela (1981), The Newly Industrializing Countries in the World Economy. New York: Pergamon Press.

(1986), "The Role of Foreign Trade in the Economic Development of Korea." In Walter Galenson (ed.), Foreign Trade and Investment: Economic Development in the Newly Industrializing Asian Countries. Madison: University of Wisconsin Press.

Baldwin, Robert E. (1975), Eoreign Trade Regimes and Economic Development: The Philippines. New York: National Bureau of Economic Research.

Bautista, Romero M. (1980), "Trade Strategies and Industrial 
Development in the Philippines: With Special Reference to Regional Trade." In Ross Garnaut (ed.), ASEAN in a Changing Pacific and World Economy. ' Canberra: Australian National University Press.

Beals, Ralph E. (1984), "Trade Patterns and Trends of Indonesia." Paper presented at conference, Global Implications of the Trade Patterns of East and Southeast Asia, Kuala Lumpur, January 1984.

Chen, Edward K. Y. (1984), "Hong Kong's Trade Patterns and Trends." Paper presented at conference, Global Implications of the Trade Patterns of East and Southeast Asia, Kuala Lumpur, January 1984 .

Cooper, William H. (1986), "Export-Led Development: The East Asian NICs." In Economic Changes in the Asian Pacific Rim: Policy Prospectus. Washington, D.C.: Congressional Research Service.

Frank, Charles R., Jr. (1975), " Eoreign Trade Regimes and Economic Development: Republic of Korea." In Trade Strategies for Economic Development: The Asian Experience. Manila: Asian Development Bank.

Hardt, John P. and Jean Boone (1986), "PRC Modernization and Openness - A New LDC and Socialist Model for the Pacific." In Economic Changes in the Asian Pacific Rim: Policy Prospectus. Washington, D.C.: Congressional Research Service. 
Hilton, R. Spence (1983), "Commodity Trade and Relative Returns to Eactors of Production." Journal of International Economics, $16,259-270$.

Hong, Wontack (1977), "Trade and Employment in Korea." In Narongchai Akrasanee, Seiji Naya, and Vinyr Vichit-Vadakan (eds.), Trade and Employment in Asia and the Pacific. Manila: Council for Asian Manpower Studies.

Krause, Lawrence B. (1982), U.S. Economic. Policy Toward the Association of Southeast Asian Nations -- Meeting the Japanese Challenge. Washington, D.C.: Brookings Institution.

Kuo, Shirley $W$. and John C. H. Eei (1986), "Causes and Roles of Export Expansion in the Republic of China." In Walter Galenson (ed.), Eoreign Trade and Investment: Economic Development in the Newly Industrializing Asian Countries. Madison: University of Wisconsin Press.

Liang, Kuo-Shu and Ching-Ing H. Liang (1981), "Trade Strategy and Exchange-Rate Policies in Taiwan." In Wontack Hong and Lawrence B. Krause (eds.), Trade and Growth of the Advanced Developing Countries in the Pacific Basin. Seoul: Korean Development Inst.

Lim, Chee Peng (1984), "Changes in the Malaysian Economy and Trade Trends and Prospects." Paper presented at conference, Global Implications of the Trade Patterns of East and Southeast 
Asia, Kuala Lumpur, January 4-6, 1984.

Lin, Tzong Biau and Victor Mok (1985), "Trade, Eoreign Investment, and Development in Hong Kong." In Walter Galenson (ed.), Foreign Trade and Investment: Economic Development in the Newly Industrializing Asian Countries. Madison: University of Wisconsin Press.

-...- and Yin Ping Ho (1981), "Export-Oriented Growth and Industrial Diversification in Hong Kong." In . Wontack Hong and Lawrence B. Krause (eds.), Trade and Growth of the Advanced Developing Countries in the Pacific Basin. Seoul: Korea Development Institute.

Nam, Chong Hyun. (1981), "Trade, Industrial Policies, and the Structure of Protection in Korea." In Wontack Hong and Lawrence B. Krause (eds.), Trade and Growth of the Advanced Developing Countries in the Pacific Basin. Seoul: Korean Development Institute.

Naya, Seiji (1986), "Trade and Investment opportunities in the NICs and ASEAN Countries and the Role of the United States." Presented at a Symposium on U.S. Pacific Relations, Joint Economic Committee of the U.S. Congress, Washington, D.C., December 11, 1986 .

Niksch, Larry A. (1986), "Indonesia, Malaysia, the Philippines, 
and Thailand." In Economic Changes in the Asian Pacific Rim: Policy Prospectus. Washington, D.C.: Congressional Research Service.

Pitt, Mark M. (1985), The Timing and Sequencing of a Trade Liberalization Policy: Indonesia. Draft study prepared for World Bank research project.

Ranis, Gustav and Chi Schive (1986), "Direct Foreign Investment in Taiwan's Development." In Walter Galenson (ed.), Foreign Trade and Investment: Economic Development in the Newly Industrializing Asian Countries. Madison: University of Wisconsin Press.

Roberts, Bee-Yan (1985), The Timing and Sequencing of a Trade Liberalization Policy: The Case of Singapore. Draft study prepared for World Bank research project.

Rosendale, Phillis (1977), "Trade and Employment in Indonesia." In Narongchai Akrasanee, Seiji Naya, and Vinyr Vichit-Vadakan (eds.), Trade and Employment in Asia and the Pacific. Manila: Council for Asian Manpower studies.

U.S. Department of Commerce, Office of Economic Research, Staff Economic Report (1976), "Alternative Measurements of TechnologyIntensive Trade," OER/ER-17, (September).

Wong, Kum Poh (1981), "The Einancing of Trade and Development in 
the ADCs: The Experience of Singapore." In Wontack Hong and Lawrence B. Krause (eds.), Trade and Growth of the Advanced Developing Countries in the Pacific Basin. Seoul: Korean Development Institute.

World Bank (1980), Thailand: Industrial Development Strategy in Thailand. Washington, D.C.: World Bank.

World Bank (1981), Indonesia: Selected Issues of Industrial Development and Trade Strategy. Washington, D.C.: World Bank.

Yue, Chia Siow (1980), "Singapore's Trade and Development Strategy, and ASEAN Economic Co-operation, with Special Reference to the ASEAN Common Approach to Eoreign Economic Relations." In Ross Garnaut (ed.), ASEAN in a Changing Pacific and World Economy. Canberra: Australian National University Press.

(1986), "The Role of Foreign Trade and Investment in the Development of Singapore." In Walter Galenson (ed.), Eoreign Trade and Investment: Economic Development in the Newly Industrializing Asian Countries. Madison: University of Wisconsin Press. 


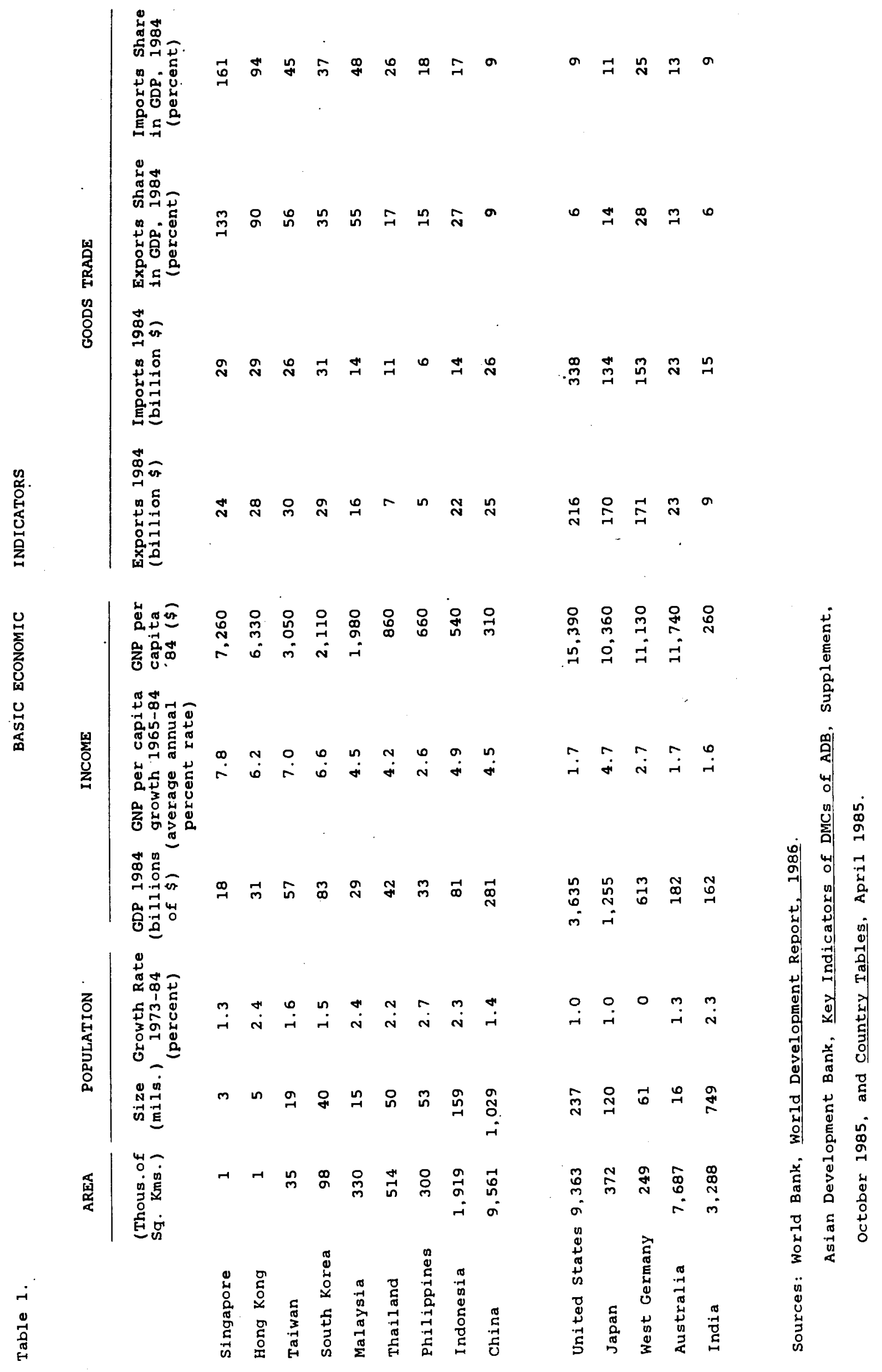


Table 2 .

SAVINGS AND INVESTMENT RATES
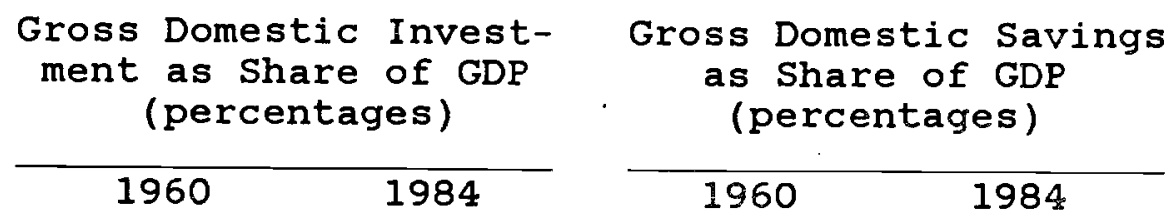

Resource Gap

(percentages)

\begin{tabular}{|c|c|c|c|c|c|c|}
\hline & & & & & & \\
\hline & 1960 & 1984 & 1960 & 1984 & 1960 & 1984 \\
\hline Singapore & 11 & 47 & 3 & 43 & -8 & -4 \\
\hline Hong Kong & 19 & 24 & 1 & 29 & -18 & 5 \\
\hline Taiwan & 20 & 22 & 13 & 33 & -7 & 12 \\
\hline South Korea & 11 & 29 & 1 & 30 & -10 & 1 \\
\hline Malaysia & 14 & 31 & 27 & 32 & 13 & 1 \\
\hline Thailand & 16 & 23 & 17 & 21 & 1 & -2 \\
\hline Philippines & 16 & 18 & 16 & 18 & 0 & 0 \\
\hline Indonesia & 8 & 21 & 8 & 20 & 0 & -1 \\
\hline China & $25^{b}$ & 30 & $25^{\circ}$ & 30 & 0 & 0 \\
\hline United States & 18 & 19 & 19 & 16 & 1 & -3 \\
\hline Japan & 34 & 28 & 34 & 31 & 0 & 3 \\
\hline West Germany & 27 & 21 & 29 & 23 & 2 & 2 \\
\hline Australia & 29 & 21 & 25 & 19 & -4 & -2 \\
\hline India & 17 & 24 & 14 & 22 & -3 & -2 \\
\hline
\end{tabular}

a $\quad 1965$

Sources: World Bank, World Development Report, 1979.

World Bank, World Development Report, 1986.

Asian Development Bank, Key Indicators of Developing Country Member Countries of ADB, 1984.

Asian Development Bank, ADB Annual Report, 1985. 
Total Long-Term Debt Disbursed \& Outstanding (millions of dollars)
Total Long-Term Debt Service as Percentage of Exports of Goods and Services

$\underline{1970}$

1984

Singapore

$152^{*}$

$\underline{1984}$

$1,911^{*}$

.6

$.8^{\mathrm{d}}$

Hong Kong

$2 \cdot$

$270^{*}$

$0^{2}$

o*
Taiwan

$1,195^{b}$

$6,147^{\circ}$

29,990

$11,846^{*}$

10,936

14,135

26,683

20.3

$4.3^{\circ}$

South Korea 1,972

$390^{*}$

726

Philippines 1,494

Indonesia

2,904

- Long-term public and publicly guaranteed debt

b External public debt outstanding, 1971

- External public debt outstanding, 1981

d 1982, long-term public and publicly guaranteed debt

- External public debt outstanding

Sources: World Bank, World Development Report, 1984.

World Bank, World Development Report, 1986.

Asian Development Bank, Key Indicators of Developing

Member Countries of ADB, April 1984. 
Table 4

GROWTH RATES OF GDF AND FOREIGN TRADE

$\begin{array}{ccccc}\begin{array}{c}\text { GDP } \\ \text { (percentages) }\end{array} & \begin{array}{c}\text { Exports } \\ \text { (percentages) }\end{array} & \begin{array}{c}\text { Imports } \\ \text { (percentages) }\end{array} & \begin{array}{c}\text { Terms of } \\ \text { Trade } \\ (1980=100)\end{array} \\ 1965-73 \quad 1973-84 & 1965-73 \quad 1973-84 & 1965-73 \quad 1973-84 & 19821984\end{array}$

\begin{tabular}{|c|c|c|c|c|c|c|c|c|}
\hline Singapore & 13.0 & 8.2 & 11.0 & 7.1 & 9.8 & 7.1 & 100 & 101 \\
\hline Hong Kong & 7.9 & 9.1 & 11.7 & 12.9 & 10.6 & 9.3 & 110 & 109 \\
\hline Taiwan & 7.9 & $9.3^{4}$ & $23.7^{b}$ & $16.7^{\circ}$ & $17.9^{b}$ & $13.5^{\circ}$ & - & - \\
\hline South Korea & 10.0 & 7.2 & 31.7 & 15.1 & 22.4 & 9.7 & 100 & $100^{\circ}$ \\
\hline Malaysia & 6.7 & 7.3 & 8.0 & 7.5 & 4.4 & 8.9 & 85 & 93 \\
\hline Thailand & 7.8 & 6.8 & 6.9 & 10.4 & 4.4 & 5.9 & 77 & 81 \\
\hline Phílippines & 5.4 & 4.8 & 4.2 & 5.6 & 3.0 & 2.3 & 89 & 101 \\
\hline Indonesia & 8.1 & 6.8 & 11.1 & 1.4 & 14.0 & 10.5 & 105 & 101 \\
\hline China & 7.8 & 6.6 & - & 10.1 & - & 10.2 & 106 & $101^{\circ}$ \\
\hline Uniteo states & 3.2 & 2.3 & 6.8 & 2.3 & 9.4 & 3.8 & 106 & 112 \\
\hline Japas & 9.8 & 4.3 & 14.7 & 7.5 & 14.9 & 1.6 & 103 & 109 \\
\hline West Germany & 4.6 & 2.0 & 10.7 & 4.5 & 11.3 & 3.9 & 97 & 96 \\
\hline Âstralia & 5.6 & 2.4 & 9.3 & 3.0 & 6.8 & 3.4 & 98 & 95 \\
\hline Indis & 3.9 & 4.1 & 2.4 & 3.3 & -5.7 & 5.4 & 104 & 107 \\
\hline
\end{tabular}

1973-83

b $1960-70$

c $\quad 1970-77$

Sources: World Bank, World Development Report, 1979.

World Bank, World Development Report, 1986.

Asian Development Bank, Key Indicators of Developing Member

Countries of ADB, 1984 . 
Table 5 . COMMODITY STRUCTURE OE PRODUCTION AND TRADE
(percentage shares)

$$
\text { (percentage shares) }
$$

PRODUCTION, $1984 \cdot$ EXPORTS, 1983

IMPORTS

Agricul- Industry Services Primary Manufacture

\begin{tabular}{|c|c|c|c|c|c|c|c|}
\hline Singapore & 1 & 39 & 60 & 44 & 56 & 44 & 56 \\
\hline Hong Kong & 1 & 22 & 78 & 8 & 92 & 25 & 75 \\
\hline Taiwan & - & - & - & 6 & $94^{4}$ & - & - \\
\hline South Korea & 14 & 40 & 47 & 9 & 91 & 49 & 51 \\
\hline Malaysia & 21 & 35 & 44 & 78 & 22 & 28 & 72 \\
\hline Thai land & 20 & 28 & 52 & 68 & 32 & 36 & 64 \\
\hline Philippines & 25 & 34 & 41 & 49 & 51 & 40 & 60 \\
\hline Indonesia & 26 & 40 & 34 & 92 & 8 & 38 & 62 \\
\hline China & 36 & 44 & 23 & 43 & 57 & 34 & 66 \\
\hline United States & 4 & 43 & 54 & 30 & 70 & 37 & 63 \\
\hline Japan & 3 & 41 & 56 & 3 & 97 & 77 & 23 \\
\hline West Germany & 2 & 46 & 52 & 13 & 87 & 42 & 58 \\
\hline Australia & - & - & - & 77 & 23 & 20 & 80 \\
\hline India & 35 & 27 & 38 & 47 & 53 & 50 & 50 \\
\hline
\end{tabular}

- 1982

Source: World Bank, World Development Report, 1986. 
Table 6 .

1981

Exports

Imports

Balance

1982

Exports

Imports

Balance

1983

Exports

Imports

Bal ance

1984

Exports

Imports

Balance

1985

Exports

Imports

Balance
MERCHANDISE TRADE OE FOUR INDEBTED COUNTRIES

IN THE ASIAN PACIEIC RIM, 1981-1985

(Billions of dollars, exports (f.o.b.), imports (c.i.f.))

Korea $\quad$ Philippines

Thail and

Indonesia

21.1

5.7

7.0

22.3

26.1

8.5

9.9

13.3

4.9

$-2.8$

$-2.9$

9.0

21.9

5.0

7.0

22.3

24.3

8.3

8.6

16.9

$-2.4$

$-3.3$

$-1.6$

5.4

24.5

4.9

6.4

21. 1

26.2

8.0

10.3

16.3

$-1.7$

$-3.1$

$-3.9$

4. 8
29.2

5.3

6.4

$-1.1$

$-1.4$

30.3

4. 6

5.5

$-.9$

31.1

$-.8$
7.4

10.4

$-3.0$

7. 1

19.7
9.2

$-2.1$
21.9

13.9

8.0

Source: International Trade, 1984-85, Table A-4, and International Trade, 1985-86, Table A-14, both from General Agreement on Tariffs and Trade (GATT). 
Table 7 .

STRUCTURE OE HONG KONG'S MERCHANDISE TRADE, 1960, 1978, AND 1983

(percentage distribution)

$\underline{\text { Exports }}$

$\begin{array}{ccccc}\begin{array}{c}\text { Fuels, minerals } \\ \text { and metals }\end{array} & \begin{array}{c}\text { Other } \\ \text { primary } \\ \text { commodities }\end{array} & \begin{array}{c}\text { Textiles \& } \\ \text { Clothing }\end{array} & \begin{array}{c}\text { Machinery \& } \\ \text { Transport } \\ \text { Equipment }\end{array} & \begin{array}{c}\text { Other } \\ \text { Manufac- } \\ \text { tures }\end{array} \\ 5 & 15 & 45 & 4 & 31 \\ 1 & 2 & 46 & 15 & 36 \\ 2 & 6 & 33 & 22 & 36\end{array}$

Imports

$\begin{array}{ccccc}\text { Food } & \text { Fue1 } & \begin{array}{c}\text { Other } \\ \text { primary } \\ \text { commodities }\end{array} & \begin{array}{c}\text { Machinery } \\ \text { \& Transport } \\ \text { Equipment }\end{array} & \begin{array}{c}\text { Other } \\ \text { Manufac- } \\ \text { tures }\end{array} \\ 27 & 3 & 16 & 10 & 44 \\ 15 & 5 & 7 & 19 & 54 \\ 12 & 7 & 6 & 21 & 54\end{array}$

Source: World Bank, World Development Report, 1981.

World Bank, World Development Report, 1986. 
Table 8

DISTRIBUTION OF HONG KONG'S IMPORTS FROM AND EXPORTS TO SELECTED COUNTRIES OR REGIONS, 1963, 1970, 1980, AND 1984

(in percentages)

$1963 \quad 1970 \quad 1980.1984$

Imports Exports Imports Exports Imports Exports Imports Exports

U.S. $16.5 \quad 35.0$

19.4

50.3

18.3

40.7

12.1

50.1

Canada

1.9

3.0

1.0

3.7

1.0

3.2

0.6

3.6

Japan

29.3

4.3

34.2

$\begin{array}{ll}4.7 & 33.8\end{array}$

4.2

28.0

4.2

Auetralia

\& N. Z .

0.0

4.9

3.6

4.4

2.7

3.9

1.8

3.5

European Community

31.2

43.9

25.6

$29.2 \quad 21.3$

36.3

13.4

22.9

ADCs

8.4

$0.4 \quad 11.1$

4.3

16.5

5.1

11.8

3.7

RRCS

8.4

7.8

4.8

2.3

6.1

3.4

2.2

2.6

Chine

0.2

0.2

$2.8 \quad 29.7$

9.0

$\overline{100.0} \overline{100.0} \overline{100}$
AD Trade Data tape.

Source: UNCTAD Trade Data tape. 
Table 9

STRUCTURE OF SINGAPORE'S MERCHANDISE TRADE,

1960, 1978, AND 1983

(percentage distribution)

\section{Exports}

Fuels, minerals and metals
Textiles
Clothing

5

5

4
Other manufactures Transport Equipment
1960

1978

1983

1960

1978

1983
31

31

$$
\text { Food }
$$

21

10

7
73

23

13
31

7

14

25

16

22

\section{Imports}

Fuels other primary commodities

\begin{abstract}
Machinery other manu\& Transport factures Equipment
\end{abstract}

38 7

21

15

24

9

29

23

31

6

30

26

Source: World Bank, World Development Report, 1981.

World Bank, World Development Report, 1986. 
Table 10.

\begin{abstract}
DISTRIBUTION OE SINGAPORE'S IMPORTS FROM AND EXPORTS TO SELECTED COUNTRIES OR REGIONS, 1963, 1970, 1980, AND 1984 (in percentages)
\end{abstract}

$1963 \quad 1970 \quad 1980 \quad 1984$

Imports Exports Imports Exports Imports Exports Imports Exports

$\begin{array}{lrrrrrrrr}\text { U.S. } & 7.3 & 13.3 & 12.9 & 18.9 & 18.2 & 17.8 & 21.7 & 26.9 \\ \text { Canada } & - & 1.8 & 0.6 & 2.0 & 1.0 & 0.9 & 0.6 & 1.0 \\ \begin{array}{l}\text { Japan } \\ \begin{array}{l}\text { Australia } \\ \text { \& N. Z. }\end{array}\end{array} & 16.0 & 7.7 & 24.3 & 13.0 & 24.0 & 10.8 & 28.1 & 11.8 \\ \begin{array}{l}\text { European } \\ \text { Community }\end{array} & 25.7 & 6.9 & 5.5 & 5.1 & 3.6 & 7.9 & 4.2 & 5.3 \\ \begin{array}{l}\text { ADCs } \\ \text { RRCs }\end{array} & 1.6 & 6.3 & 5.3 & 9.6 & 3.9 & 15.1 & 5.1 & 12.3 \\ \text { China } & 44.2 & 32.8 & 33.3 & 18.8 & 34.1 & 29.5 & 16.2 & 29.2 \\ & - & 0.9 & - & 2.5 & - & 2.0 & 7.7 & 1.2 \\ & 100.0 & 100.0 & 100.0 & 100.0 & 100.0 & 100.0 & 100.0 & 100.0\end{array}$

Source: UNCTAD Trade Data tape. 
Table 11

STRUCTURE OF KOREA'S MERCHANDISE TRADE,

$$
\begin{gathered}
1960,1978, \text { AND } 1983 \\
\text { (percentage distribution) } \\
\text { Exports }
\end{gathered}
$$

Fuels, minerals and metals

30

1

3

1983

1960

1978

1983
10

8

8
Food

Other
primary
commodities

56

10

6 Textiles \&
Clothing

8

32

25

32 other manuTransport factures Equipment

\section{Imports}

Euels

Other
primary
commodities

Machinery other manucommodities \& Transport Equipment

25

12

46

7

17

33

26

27

14

29

22

Source: World Bank, World Development Report, 1981.

World Bank, World Development Report, 1986. 
Table 12

DISTRIBUTION OF KOREA'S IMPORTS EROM AND EXPORTS TO SELECTED COUNTRIES OR REGIONS, 1963, 1970, 1980, AND 1984

(in percentages)

1963

1970

1980

1984

Imports Exports Imports Exports imports Exports Imports Exports

U.S.

49.5

32.5

31.1

50.7

33.7

35.2

33.5

46.4

Canada

0.7

0.3

1.1

2.5

3.3

2.6

3.2

3.8

Japan

34.7

49.4

29.8

40.4

23.0

$41.2 \quad 20.2$

Australia

\& N. Z.

1.8

0.3

0.9

1.0

3.9

1.9

5.3

1.9

European

Community

$7.1 \quad 9.3$

9.4

8.6

10.0

20.8

10.1

14.5

ADCs

$4.0 \quad 18.4$

2.5

5.9

2.3

9.9

2.2

8.9

RRCs

1.8

4.5

5.2

1.3

6.0

6.3

4.1

3.9

China

\begin{tabular}{|c|c|c|c|c|c|c|c|}
\hline - & - & - & - & - & - & - & - \\
\hline 100.0 & 100.0 & 100.0 & 100.0 & 100.0 & 100.0 & 100.0 & 100.0 \\
\hline
\end{tabular}

Source: UNCTAD Trade Data tape. 


\section{Table 13}

DISTRIBUTION OF TAIWAN'S IMPORTS FROM AND EXPORTS TO SELECTED COUNTRIES OR REGIONS, 1963, 1970, 1980, AND 1984 (in percentages)

$1963 \quad 1970 \quad 1980 \quad 1984$

Imports Exports Imports Exports Imports Exports Imports Exports

U.S.

43.1

19.9

25.7

44.2

33.0

31.7

Canada

1.1

2.1

1.3

3.9

1.6

3.5

Japan

34.7

38.4

51.7

16.7

40.4

40.7

Australia
$\&$ N. Z.

5.0

1.2

3.0

1.6

3.4

4.9

European

Community

$7.1 \quad 10.2$

8.7

11.0

9.8

10.4

ADCs

$2.4 \quad 20.5$

$3.3 \quad 15.6$

5.3

5.6

RRCs

6.4

7.3

6.0

6.6

6.1

2.8

China

$0.0 \quad 0.0$

0.0

0.0

0.0

0.0

0.0

0.0

$100.0 \cdot 100.0$

100.0

$100.0 \quad 100.0$

100.0

Source: UNCTAD Trade Data tape. 
Table 14

STRUCTURE OF THE PHILIPPINES' MERCHANDISE TRADE,

1960, 1978,' AND 1983

(percentage distribution)

\section{Exports}

Fuels, minerals and metals

10

14

13

1983

1978

1978

1983

Food

Other
primary
commodities

Textiles \& Clothing

86

52

36

1

6

7 Machinery \&
Transport
Equipment
Other manufactures
3

26

38

\section{Imports}

Euels

Other primary commodities

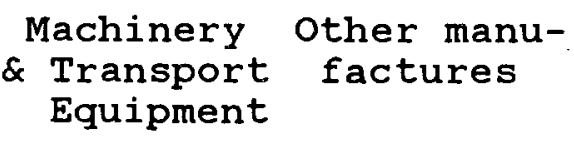

5

36

34

21

7

27

37

27

21

39

Source: World Bank, World Development Report, 1981.

World Bank, World Development Report, 1986. 


\section{Table 15}

DISTRIBUTION OF THE PHILIPPINES' IMPORTS FROM AND EXPORTS TO SELECTED COUNTRIES OR REGIONS, 1963, 1970, 1980, AND 1984 (in percentages)

1963

1970

1980

1984

Imports Exports Imports Exports Imports Exports Imports Exports

U.S.

Canada

Japan

Australia

\& N. Z.

\section{European}

Community

ADCs

RRCs

China
$46.6 \quad 30.3$

42.7

0.1

2.4

0.2

38.0

40.5

22.128 .0

0.3

4.5

0.4

8.7

17.7

2.2

6.7

4.6

0.4

0.0

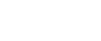

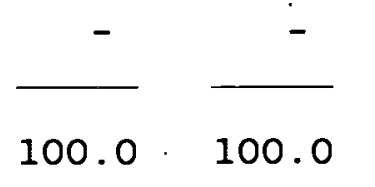

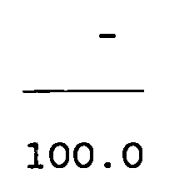
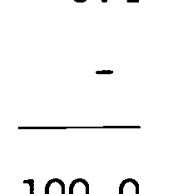

4.2

34.3

1.6

29.1

26.6

1.0

32.7

2.1

14.0

20.6

9.6

11.0

6.9

4.6

1.0

$-$

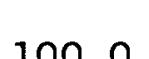

100.0
38.6

1.0

24.5

3.2

11.8

10.9

4. 3

5.4 100.0

Source: UNCTAD Trade Data tape. 
Table 16

STRUCTURE OE MALAYSIA'S MERCHANDISE TRADE,

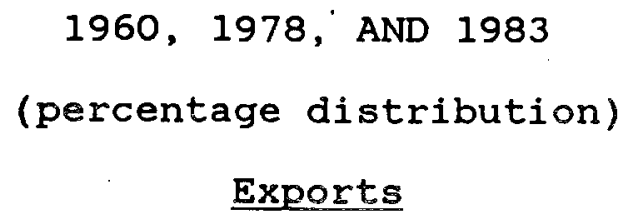

Exports

$\begin{array}{cc}\text { Fuels, minerals } & \begin{array}{c}\text { other } \\ \text { and metals }\end{array} \\ \text { commodities }\end{array}$

20

27

35

1978
1983

1960
1978
1983

1978
1983

1960
1978
1983

1978
1983

1960
1978
1983

1978
1983

1960
1978
1983

Source:

Food

Fuels

9

14

\section{Textiles \& Clothing}

74

52

43

2

2 Machinery \&
Transport
Equipment
Other manufactures

\section{6}

Other manufactures
11

8

14

6

\section{Imports}

Other
primary
commodities
Machinery
\& Transport
Equipment commodities

$\begin{array}{rrrr}16 & 13 & 14 & 28 \\ 13 & 7 & 34 & 29 \\ 14 & 5 & 44 & 28\end{array}$

28

29

44

World Bank, World Development Report, 1981.

World Bank, World Development Report, 1986. 
Table 17

DISTRIBUTION OF MALAYSIA'S IMPORTS EROM AND EXPORTS TO SELECTED COUNTRIES OR REGIONS, 1963, 1970, 1980, AND 1984 (in percentages)

$\begin{array}{llll}1963 & 1970 & 1980 & 1984\end{array}$

Imports Exports Imports Exports Imports Exports Imports Exports

\begin{tabular}{|c|c|c|c|c|c|c|c|c|}
\hline U.S. & - & 12.6 & 10.7 & 14.9 & 14.4 & 18.3 & 15.6 & - \\
\hline Canada & 0.4 & 2.0 & 2.3 & 2.2 & 0.9 & 0.5 & 1.2 & - \\
\hline Japan & 4.4 & 24.7 & 3.6 & 21.0 & 23.1 & 25.7 & 24.8 & - \\
\hline $\begin{array}{c}\text { Australia } \\
\& \text { N. Z. }\end{array}$ & 2.6 & 2.5 & 11.6 & 3.0 & 6.2 & 2.0 & 4.3 & - \\
\hline $\begin{array}{l}\text { European } \\
\text { Community }\end{array}$ & 16.7 & 24.8 & 42.4 & 23.2 & 15.7 & 19.8 & 11.8 & - \\
\hline ADCs & 66.4 & 28.8 & 22.6 & 30.3 & 35.2 & 27.9 & 36.6 & - \\
\hline RRCs & 9.2 & 4.1 & 6.6 & 3.6 & 4.3 & 3.6 & 3.7 & - \\
\hline China & - & 0.1 & - & 1.4 & - & 1.8 & 1.7 & - \\
\hline
\end{tabular}

Source: UNCTAD Trade Data tape. 
Table 18

STRUCTURE OF THAILAND'S MERCHANDISE TRADE, 1960, 1978,' AND 1983

(percentage distribution)

Exports
Fuels, minerals and metals

1960

1978

1983

1960

1978

1983

\section{7}

11

6

Food

10

4

4

Other
primary
commodities

\section{Textiles Clothing}

91

64

62
0

10

11
Machinery \& Transport Equipment

0

3

12

6

15
2

12

Imports

Fuels

Other
primary
commodities

11

21

24
11

9

8
Machinery other manu\& Transport factures Equipment

25

43

31

35

29 
Table 19

DISTRIBUTION OF THAILAND'S IMPORTS FROM AND EXPORTS TO SELECTED COUNTRIES OR REGIONS, 1963, 1970, 1980, AND 1984 (in percentages)

$1963 \quad 1970 \quad 1980.1984$

Imports Exports Imports Exports Imports Exports Imports Exports

\begin{tabular}{|c|c|c|c|c|c|c|c|c|}
\hline U.S. & 18.7 & 9.6 & 14.8 & 15.0 & 19.1 & 15.3 & 15.7 & 22.4 \\
\hline Canada & 0.5 & 0.0 & 0.7 & 0.1 & 2.1 & 0.4 & 1.2 & 1.5 \\
\hline Japan & 34.6 & 25.6 & 44.9 & 29.5 & 33.6 & 18.9 & 36.7 & 17.0 \\
\hline $\begin{array}{c}\text { Australia } \\
\& \mathrm{~N} . \mathrm{Z}\end{array}$ & 1.9 & 0.3 & 3.6 & 0.5 & 3.2 & 1.3 & 2.6 & 2.3 \\
\hline $\begin{array}{l}\text { European } \\
\text { Community }\end{array}$ & 28.7 & 22.9 & 24.3 & 22.2 & 18.0 & 32.6 & 15.9 & 26.9 \\
\hline $\mathrm{ADCs}$ & 11.6 & 26.3 & 9.6 & 23.1 & 18.8 & 18.0 & 22.2 & 19.2 \\
\hline RRCs & 1.5 & 14.9 & 1.7 & 9.3 & 4.9 & 10.7 & 1.4 & 7.1 \\
\hline China & - & - & - & - & - & 2.4 & 3.8 & 3.1 \\
\hline & 100.0 & 100.0 & 100.0 & 100.0 & 100.0 & 100.0 & 100.0 & 100.0 \\
\hline
\end{tabular}

Source: UNCTAD Trade Data tape. 
Table 20

STRUCTURE OF INDONESIA'S MERCHANDISE TRADE,

$$
\begin{gathered}
1960,1978, \text { AND } 1983 \\
\text { (percentage distribution) }
\end{gathered}
$$

Exports

$\begin{array}{cc}\text { Fuels, minerals } & \text { Other } \\ \text { and metals } & \begin{array}{c}\text { primary } \\ \text { commodities }\end{array}\end{array}$

33

72

80

1983

1960

1978

Eood
Textiles
Clothing

0

$-$

1

12

67

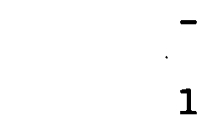
Machinery \& Transport Equipment

other manufactures

26

1

1

6

Imports

$$
\begin{gathered}
\text { other } \\
\text { primary } \\
\text { commodities }
\end{gathered}
$$

\begin{abstract}
Machinery \& Transport Equipment
\end{abstract}

Other manufactures

1960

$$
23
$$

5

10

17

45

1978

18

9

6

36

31

8

25

35

28

Source: World Bank, World Development Report, 1981..

World Bank, World Development Report, 1986. 
Table 21

DISTRIBUTION OF INDONESIA'S IMPORTS EROM AND EXPORTS TO SELECTED COUNTRIES OR REGIONS, 1963, 1970, 1980, AND 1984

(in percentages)

1963

1970

1980

1984

Imports Exports Imports Exports Imports Exports Imports Exports

U.S.

21.8

28.2

15.9

17.3

20.9

16.8

22.4

Canada

0.2

1.7

0.0

2.2

0.1

3.1

0.2

Japan

20.7

$34.5 \quad 37.9$

42.8

52.5

43.0

51.7

Australia

\& N. Z .

0.8

3.9

3.9

5.3

2.1

4.0

2.4

European

Community

29.2

ADCs

19.3

23.2

18.4

22.3

6.9

26.8

5.3

RRCs

7.6

$5.2 \quad 20.8$

5.2

15.9

4.3

15.9

China

3.0

2.8

4.6

1.3

0.6

1.8

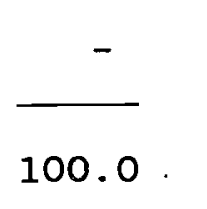

$-$

0.0

0.9

0.0

100.0

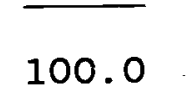

100.0

100.0

$$
100.0
$$

100.0

100.0

Source: UNCTAD Trade Data tape. 
Table 22

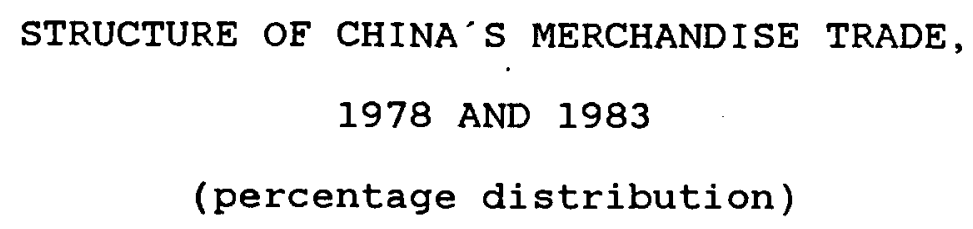

Exports

Fuels, minerals and metals

1978

1983

13

22

Food

17

15
Textiles
Clothing primary commodities
Machinery \& Other manuTransport Equipment

factures
24

19
3

6
22

32

\section{Imports}

$$
\text { Euels }
$$

0

1

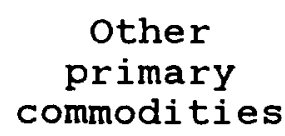

43

18
Machinery other manu\& Transport factures Equipment

18

22

19

Source: World Bank, World Development Report, 1981. World Bank, World Development Report, 1986. 


\section{Table 23}

DISTRIBUTION OF CHINA'S IMPORTS FROM AND EXPORTS TO SELECTED COUNTRIES OR REGIONS, 1963, 1970, 1980, AND 1984

$$
\text { (in percentages) }
$$

1963

1970

1980

1984

Imports Exports Imports Exports Imports Exports Imports Exports

y.S.

Canada

Japan

Australia

\& N. Z.

European

Community

$\mathrm{ADCs}$

RRCs

China
38.6

$-$

29.1

1.2

0.3

$-$
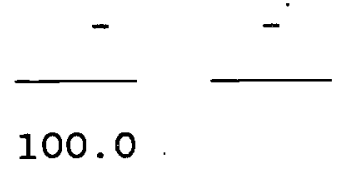

100.0
$-$

10.1

42.3

9.9

26.5

5.2

35.5

6.5

$$
33.8
$$

2.0

1.6

$-$

4.2

2.7
17.9

5.5

43.0

5.1

1.3

19.0

-

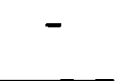

17.4

9.7

1.1

3.9
12.1

1.3

26.9

100.0

$100.0 \quad 100.0$

Source: UNCTAD Trade Data tape. 
Table 24

\begin{abstract}
DISTRIBUTION OE U.S. EXPORTS TO AND IMPORTS EROM
\end{abstract}
SELECTED REGIONS, 1968, 1975, AND 1982

(in percentages)

\begin{tabular}{|c|c|c|c|c|c|c|}
\hline & \multicolumn{6}{|c|}{ All Goods } \\
\hline & \multicolumn{2}{|c|}{$\underline{1968}$} & \multicolumn{2}{|c|}{$\underline{1975}$} & \multicolumn{2}{|c|}{1982} \\
\hline & Exports & Imports & Exports & Imports & Exports & Imports \\
\hline ADCs & 3.7 & 3.4 & 4.6 & 5.7 & 7.1 & 9.3 \\
\hline RRCs & 2.8 & 3.1 & 3.1 & 4.8 & 4.6 & 4.5 \\
\hline China & - & - & 0.3 & $0: 2$ & 1.4 & 0.9 \\
\hline South Asia & 3.1 & 1.2 & 2.0 & 0.7 & 1.1 & 0.7 \\
\hline European Community & 27.0 & 25.7 & 23.5 & 18.0 & 24.2 & 17.8 \\
\hline Other Western Europe & 4.6 & 4.2 & 3.6 & 3.1 & 3.4 & 3.2 \\
\hline Japan & 8.5 & 12.6 & 8.8 & 12.0 & 9.9 & 15.8 \\
\hline Australia/New Zealand & .2 .9 & 1.4 & 2.1 & 1.4 & 2.6 & 1.2 \\
\hline Canada & 23.5 & 26.8 & 20.1 & 22.5 & 15.4 & 18.8 \\
\hline Rest of World & 23.9 & 21.6 & 31.9 & 31.6 & 30.3 & 27.8 \\
\hline
\end{tabular}

Source: Trade data bank of author. 
Table 25 .

SHARES OF THE UNITED STATES AND SELECTED FOREIGN COMPETITORS

IN EXPORTS TO APR COUNTRIES ${ }^{a}$

(in percentages)

$\frac{1963}{\text { ADCS RRCS China ADCS RRCs China ADCs RRCS China }} \frac{1970}{1980^{\mathrm{b}}}$
Total Exports from All Row Countries

$\begin{array}{lrrrrrrrrrrrr}\text { U.S. } & 20 & 24 & 0 & 18 & 20 & 0 & 21 & 16 & 27 & 21 & 16 & 18 \\ \text { Canada } & 1 & 1 & 18 & 1 & 2 & 10 & 1 & 1 & 5 & 2 & 1 & 6 \\ \text { Japan } & 22 & 21 & 12 & 33 & 30 & 42 & 28 & 26 & 36 & 30 & 26 & 43 \\ \text { Aust. \& N.Z. } & 3 & 2 & 39 & 3 & 5 & 10 & 3 & 4 & 7 & 3 & 3 & 5 \\ \text { EC } & 17 & 20 & 29 & 14 & 22 & 39 & 12 & 14 & 19 & 11 & 13 & 17 \\ \text { ADCs } & 8 & 23 & 1 & 10 & 15 & 2 & 12 & 30 & 4 & 12 & 35 & 10 \\ \text { RRCsC } & 29 & 9 & 0 & 21 & 7 & 2 & 23 & 8 & 3 & 11 & 4 & 1 \\ \text { Ris } & 0 & 0 & - & 0 & 0 & - & 0 & 0 & - & 10 & 2 & -\end{array}$

Natural Resource-Intensive Exports from A11 Row Countries ${ }^{d}$

\begin{tabular}{|c|c|c|c|c|c|c|c|c|c|c|c|}
\hline U.S. & 21 & 22 & 0 & 20 & 27 & 0 & 20 & 13 & 52 & 23 & 13 \\
\hline Canada & 1 & 3 & 26 & 1 & 2 & 28 & 2 & 3 & 12 & 4 & 3 \\
\hline inall & 7 & 7 & 2 & 13 & 13 & 9 & 8 & 7 & 7 & 10 & 6 \\
\hline Aust. \& N.Z. & 6 & 3 & 55 & 5 & 9 & 27 & 5 & 10 & 15 & 9 & 8 \\
\hline EC & 7 & 8 & 14 & 7 & 10 & 26 & 5 & 5 & 4 & 6 & 5 \\
\hline $\mathrm{ADCs}^{\mathrm{C}}$ & 9 & 34 & 2 & 8 & 19 & 5 & 13 & 40 & 3 & 13 & 47 \\
\hline $\operatorname{RRCs}^{\circ}$ & 49 & 23 & 0 & 46 & 20 & 4 & 50 & 22 & 6 & 24 & 12 \\
\hline China & 0 & 0 & - & 0 & 0 & - & 0 & 0 & - & 11 & 6 \\
\hline
\end{tabular}


Table 25. (cont.)

SHARES OF THE UNITED STATES AND SELECTED FOREIGN COMPETITORS

IN EXPORTS TO APR COUNTRIES ${ }^{a}$

\begin{tabular}{|c|c|c|c|}
\hline 1963 & 1970 & $1980^{b}$ & $1984^{b}$ \\
\hline ADCs RRCs China & ADCs RRCs China & ADCs RRCs China & ADCs RRCs China \\
\hline
\end{tabular}

$\begin{array}{lrrrrrrrrrrrr}\text { U.S. } & 11 & 20 & 0 & 6 & 13 & 0 & 7 & 7 & 22 & 5 & 7 & 6 \\ \text { Canada } & 0 & 0 & 0 & 0 & 0 & 0 & 0 & 1 & 0 & 0 & 1 & 0 \\ \text { Japan } & 49 & 33 & 35 & 53 & 37 & 40 & 42 & 23 & 47 & 31 & 24 & 37 \\ \text { Aust. \& N.Z. } & 1 & 0 & 0 & 1 & 1 & 0 & 1 & 1 & 1 & 1 & 1 & 0 \\ \text { EC } & 21 & 8 & 59 & 12 & 13 & 60 & 12 & 8 & 8 & 9 & 8 & 4 \\ \text { ADCs }^{C} & 13 & 37 & 6 & 26 & 33 & 2 & 27 & 56 & 21 & 18 & 54 & 51 \\ \text { RRCs }^{C} & 5 & 2 & 0 & 2 & 3 & 0 & 10 & 4 & 2 & 4 & 4 & 1 \\ \text { China } & 0 & 0 & - & 0 & 0 & - & 0 & 0 & - & 32 & 2 & -\end{array}$

Technology-Intensive Exports from A11 Row Countries

\begin{tabular}{|c|c|c|c|c|c|c|c|c|c|c|c|c|}
\hline U.S. & 23 & 30 & 0 & 24 & 20 & 0 & 27 & 22 & 15 & 25 & 20 & 22 \\
\hline Canada & 1 & 0 & 0 & 0 & 2 & 0 & 1 & 1 & 1 & 1 & 1 & 1 \\
\hline Japan & 35 & 23 & 32 & 43 & 34 & 56 & 39 & 32 & 50 & 40 & 32 & 44 \\
\hline Aust. \& N.Z. & 1 & 1 & 0 & 1 & 2 & 0 & 1 & 1 & 0 & 1 & 1 & 0 \\
\hline EC & 33 & 32 & 68 & 23 & 33 & 44 & 17 & 20 & 30 & 15 & 17 & 23 \\
\hline$A D C s^{C}$ & 2 & 12 & 0 & 6 & 8 & 0 & 8 & 22 & 5 & 11 & 28 & 9 \\
\hline $\operatorname{RRCs}^{c}$ & 5 & 1 & 0 & 2 & 1 & 0 & 7 & 2 & 0 & 4 & 1 & 0 \\
\hline China & 0 & 0 & - & 0 & 0 & - & 0 & 0 & - & 3 & 0 & - \\
\hline
\end{tabular}


Table 25. (cont.)

SHARES OF THE UNITED STATES AND SELECTED FOREIGN COMPETITORS

IN EXPORTS TO APR COUNTRIES ${ }^{a}$

Human Capital-Intensive Exports from All Row Countries ${ }^{d}$

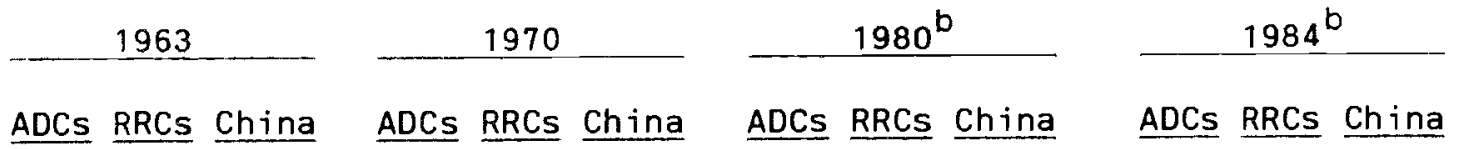

\begin{tabular}{|c|c|c|c|c|c|c|c|c|c|c|c|c|}
\hline ย.S. & 14 & 17 & 0 & 9 & 9 & 0 & 9 & 4 & 4 & 9 & 3 & 1 \\
\hline Canada & 0 & 1 & 0 & 0 & 0 & 0 & 1 & 1 & 2 & 0 & 1 & 0 \\
\hline Japan & 47 & 41 & 43 & 59 & 50 & 71 & 63 & 51 & 70 & 59 & 47 & 79 \\
\hline Aust. \& N.Z. & 2 & 1 & 6 & 3 & 6 & 0 & 3 & 3 & 5 & 1 & 2 & 2 \\
\hline$E C$ & 26 & 24 & 51 & 16 & 18 & 29 & 13 & 11 & 17 & 16 & 13 & 15 \\
\hline $\operatorname{ADCs}^{C}$ & 4 & 16 & 0 & 9 & 16 & 0 & 8 & 28 & 1 & 7 & 32 & 2 \\
\hline $\operatorname{RRCs}^{C}$ & 7 & 1 & 0 & 3 & 1 & 0 & 3 & 2 & 1 & 2 & 1 & 0 \\
\hline China & 0 & 0 & - & 0 & 0 & - & 0 & 0 & - & 4 & 1 & - \\
\hline
\end{tabular}

${ }^{a}$ Shares of total exports of countries listed.

Data for Taiwan are not included in the 1980 and 1984 figures, since the United Nations no longer recognizes Taiwan as a separate country and therefore UN agencies no longer collect data on Taiwan.

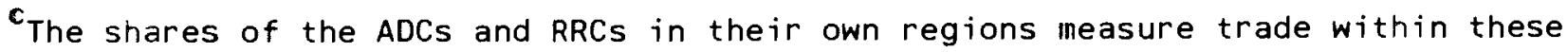
regions.

dhe commodity breakdown into goods that are natural resource-intensive, unskilled labor-intensive, technology-intensive, and human capital-intensive is adapted from Krause (1984).

Source: UNCTAD Trade Data tape. 
Table 26

DISTRIBUTION OE MAJOR U.S. EXPORTS TO AND IMPORTS EROM APR COUNTRIES, 1968,1975, AND 1982

(in percentages)

\section{Exports}

SIC Industries

$\overline{A D C s}_{\frac{1968}{\mathrm{RRCs}} \text { China }} \frac{1975}{\text { ADCs }} \frac{197}{\text { RRCs China }} \stackrel{\text { ADCs }}{\frac{1982}{\text { RRCs }} \text { China }}$

Agricultural -Crops (1)

23

14

26

11

28

$18 \quad 10$

51

Food \& kindred

products (20)

$9 \quad 13$

7

2

0 .

5

1

Lumber \& wood

products (24)

Chemicals

10

0

0

0

1

$0 \quad 7$

$8 \quad 8$

$7 \quad 12$

2

10

11

22

Primary metal

industries (33)

$2 \quad 2 \quad-$

Eabricated metal products (34)

7

Machinery, exc.

electrical(35)

$13 \quad 24$

3

$5 \quad 19$

2

2

3

Elect. \& electronic machinery (36) 9

$4-$

4

$4 \quad 13$

5

$4 \quad 0$

Transportation equipment (37)

13

13

10

9

1

$18 \quad 22$

5

\section{All other}

products

$15 \quad 16$

13

11

6

$18 \quad 22$

8

Source: Trade data bank of author.

- An industry is included if the export or export share of the industry is at least $5 \%$ in any region in any of the three years. 
Table 26 (cont.)

Imports

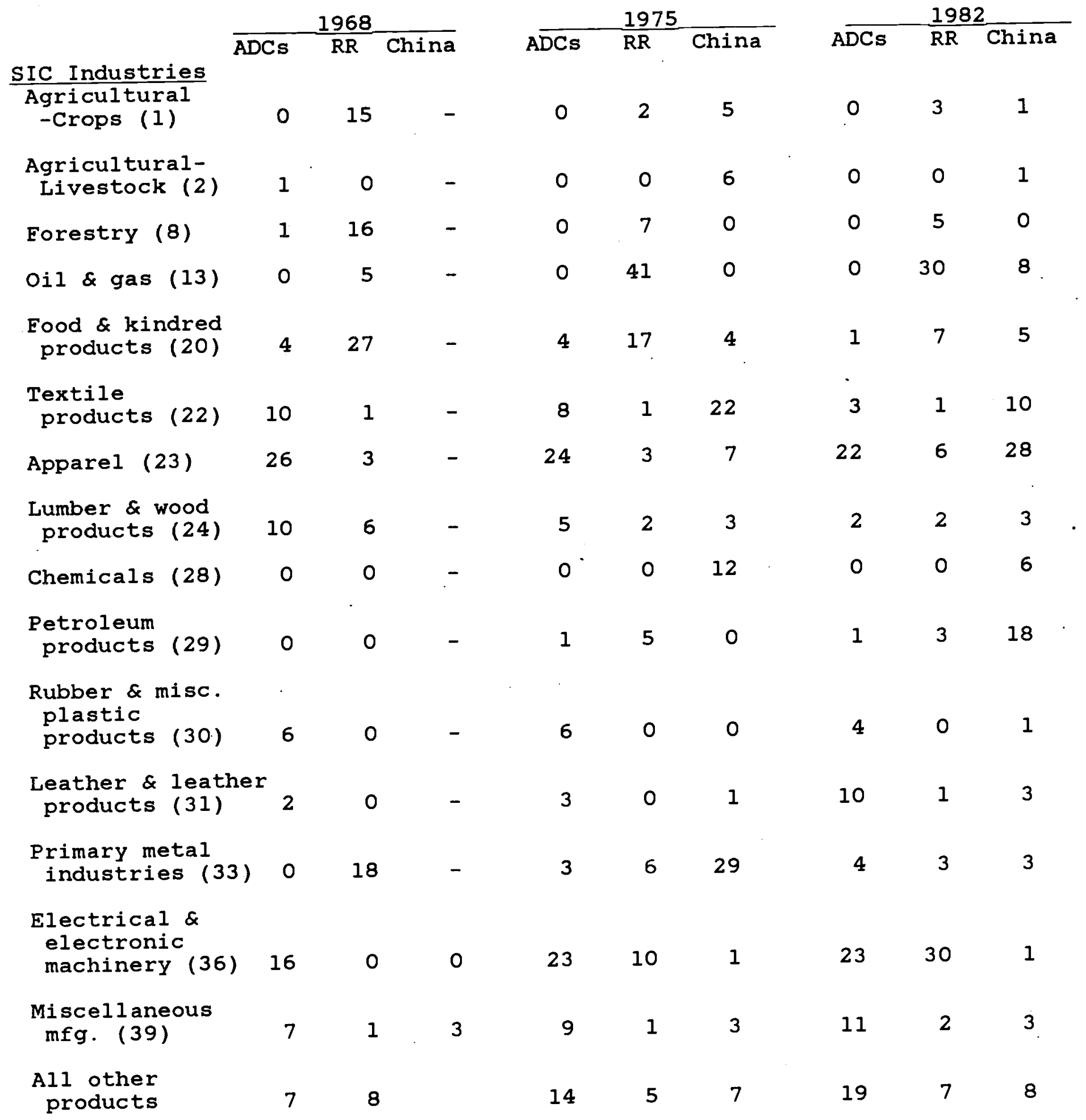


Table 27

COMPARATIVE GROWTH RATES BY FACTOR-INTENSITY BREAKDOWNS OF EXPORTS TO APR COUNTRIES, 1963-1970, 1970-1980, AND 1980-1984*

(average annual growth rates in percentages)

\section{$\underline{1963-1970}$}

$\begin{array}{lccc} & \underline{\text { ADCs }} & \text { RRCs } & \text { China } \\ \text { Natural resource-intensive } & 18.6 & 9.8 & 4.9 \\ \text { Unskilled labor-intensive } & 35.2 & 4.8 & 17.3 \\ \text { Technology-intensive } & 36.8 & 18.3 & 45.1 \\ \text { Human capital-intensive } & 27.7 & 17.9 & 15.6\end{array}$

\section{$\underline{1970-1980}$}

$\underline{\text { ADCs }} \quad \underline{\text { RRCs }} \quad \underline{\text { China }}$

$\begin{array}{lccr}\text { Natural resource-intensive } & 72.5 & 74.8 & 97.3 \\ \text { Unskilled labor-intensive } & 37.9 & 43.3 & 168.3 \\ \text { Technology-intensive } & 91.6 & 82.7 & 107.0 \\ \text { Human capital-intensive } & 76.5 & 62.0 & 56.6\end{array}$

$\underline{1980-1984}$

$\underline{\text { ADCs }} \quad \underline{\text { RRCs }} \quad \underline{\text { China }}$

$\begin{array}{lccc}\text { Natural resource-intensive } & -1.3 & -0.5 & -5.7 \\ \text { Unskilled labor-intensive } & 21.6 & 4.3 & 17.4 \\ \text { Technology-intensive } & 7.8 & 2.7 & 11.5 \\ \text { Human capital-intensive } & 0.5 & -2.2 & 12.7\end{array}$

- Exports by the U.S., Canada, Japan, Australia and New Zealand, the European Community, the ADCs, the RRCs, and China.

Source: UNCTAD Trade Data tape. 
Table 28

COMPOSITION OE U.S. EXPORTS TO AND IMPORTS FROM SELECTED REGIONS BY TECHNOLOGY INTENSITY, 1968, 1975, AND 1982

(in percentages)

\section{Technology-Intensive Goods}

Exports Imports Exports Imports Exports Imports

\begin{tabular}{|c|c|c|c|c|c|c|}
\hline ADCs & 38 & 15 & 41 & 26 & 42 & 27 \\
\hline RRCs & 24 & 0 & 40 & 25 & 52 & 54 \\
\hline China & - & - & 14 & 6 & 53 & 4 \\
\hline South Asia & 30 & 0 & 42 & 1 & 42 & 4 \\
\hline European Community & 42 & 13 & 41 & 17 & 47 & 20 \\
\hline Japan & 32 & 26 & 33 & 25 & 37 & 30 \\
\hline Australia/New Zealand & 41 & 11 & 40 & 21 & 41 & 29 \\
\hline Canada & 19 & 4 & 16 & 5 & 23 & 11 \\
\hline World & 31 & 13 & 31 & 16 & 37 & 20 \\
\hline & \multicolumn{6}{|c|}{ Non-Technology-Intensive } \\
\hline ADCs & 62 & 85 & 59 & 74 & 58 & 73 \\
\hline RRCs & 76 & 100 & 60 & 75 & 48 & 46 \\
\hline China & - & - & 86 & 94 & 47 & 96 \\
\hline South Asia & 70 & 100 & 58 & 99 & 58 & 96 \\
\hline European Community & 58 & 87 & 59 & 83 & 53 & 80 \\
\hline Japan & 68 & 74 & 67 & 75 & 63 & 70 \\
\hline Australia/New Zealand & 59 & 89 & 59 & 79 & 59 & 71 \\
\hline Canada & 81 & 96 & 85 & 95 & 77 & 89 \\
\hline World & 69 & 87 & 69 & 84 & 63 & 80 \\
\hline
\end{tabular}

Source: Trade data bank of author. 
Table 29

ESTIMATED ORDER OF RELATIVE FACTOR-PRICE DIFEERENCES BETWEEN THE UNITED STATES AND SELECTED COUNTRIES OR REGIONS, $1978^{1}$

\begin{tabular}{|c|c|c|c|c|c|}
\hline & Capital & $\begin{array}{l}\text { Unskilled } \\
\text { Labor }\end{array}$ & $\begin{array}{l}\text { Skilled } \\
\text { Labor }\end{array}$ & $\begin{array}{r}\text { Land Natural } \\
\text { Resources }\end{array}$ & $\begin{array}{l}\text { \# Obser- } \\
\text { vations }\end{array}$ \\
\hline Singapore & $\begin{array}{c}4.23 \\
(2.88)\end{array}$ & $\begin{array}{l}-3.50 \\
(-2.97)\end{array}$ & $\begin{array}{c}4.81 \\
(3.11)\end{array}$ & $\begin{array}{ll}-.96 & -89.61 \\
(-.22) & (-2.02)\end{array}$ & 203 \\
\hline Hong Kong & $\begin{array}{c}4.39 \\
(3.07)\end{array}$ & $\begin{array}{l}-5.39 \\
(-5.02)\end{array}$ & $\begin{array}{c}4.63 \\
(3.12)\end{array}$ & $\begin{array}{l}14.88 \\
(3.47)\end{array}$ & 240 \\
\hline Taiwan & $\begin{array}{c}3.10 \\
(2.07)\end{array}$ & $\begin{array}{l}-9.40 \\
(-8.25)\end{array}$ & $\begin{array}{c}6.99 \\
(4.68)\end{array}$ & $\begin{array}{lr}10.74 & 121.80 \\
(3.15) & (2.55)\end{array}$ & 240 \\
\hline Korea & $\begin{array}{c}3.76 \\
(2.42)\end{array}$ & $\begin{array}{l}-8.52 \\
(-6.98)\end{array}$ & $\begin{array}{c}7.63 \\
(4.86)\end{array}$ & $\begin{array}{cc}4.05 & 116.26 \\
(1.03) & (2.37)\end{array}$ & 236 \\
\hline Malaysia & $\begin{array}{c}7.56 \\
(2.92)\end{array}$ & $\begin{array}{l}-6.36 \\
(-3.31)\end{array}$ & $\begin{array}{c}4.44 \\
(1.81)\end{array}$ & $\begin{array}{cc}-9.36 & -128.82 \\
(-1.70) & (-1.48)\end{array}$ & 139 \\
\hline Thailand & $\begin{array}{l}2.49 \\
(1.19)\end{array}$ & $\begin{array}{l}-6.33 \\
(-4.03)\end{array}$ & $\begin{array}{l}10.29 \\
(4.82)\end{array}$ & $\begin{array}{l}-4.34 \\
(-.96)\end{array}$ & 157 \\
\hline Philippine & $\begin{array}{r}2.39 \\
(1.25)\end{array}$ & $\begin{array}{l}-5.36 \\
(-3.71)\end{array}$ & $\begin{array}{l}10.03 \\
(4.78)\end{array}$ & $\begin{array}{l}-2.97 \\
(-.61)\end{array}$ & 193 \\
\hline Indonesia & $\begin{array}{l}-.05 \\
(-.02)\end{array}$ & $\begin{array}{l}-4.92 \\
(-2.86)\end{array}$ & $\begin{array}{l}13.27 \\
(4.77)\end{array}$ & $\begin{array}{ll}-12.52 & -201.86 \\
(-2.75) & (-2.27)\end{array}$ & 109 \\
\hline All & $\begin{array}{c}4.26 \\
(3.30)\end{array}$ & $\begin{array}{l}-6.81 \\
(-6.55)\end{array}$ & $\begin{array}{c}5.67 \\
(4.07)\end{array}$ & $\begin{array}{l}-7.50 \\
(-.18)\end{array}$ & 274 \\
\hline ASEAN & $\begin{array}{c}3.35 \\
(2.26)\end{array}$ & $\begin{array}{l}-4.30 \\
(-3.68)\end{array}$ & $\begin{array}{l}6.69 \\
(4.26)\end{array}$ & $\begin{array}{ll}-5.51 & -92.68 \\
(-1.36) & (-2.00)\end{array}$ & 242 \\
\hline China & $(.47)$ & $\begin{array}{l}-6.45 \\
(-1.96)\end{array}$ & $\begin{array}{l}10.84 \\
(2.82)\end{array}$ & $\begin{array}{l}5.45-183.90 \\
(.89)(-1.22)\end{array}$ & 89 \\
\hline Japan & $\begin{array}{c}5.42 \\
(4.57)\end{array}$ & $\begin{array}{l}-4.12 \\
(-4.30)\end{array}$ & $\begin{array}{l}-1.92 \\
(-1.51)\end{array}$ & $\begin{array}{lr}18.29 & 130.50 \\
(6.04) & (3.18)\end{array}$ & 281 \\
\hline
\end{tabular}

Source: Trade data bank of author.

1 The $t$ statistic is in parentheses under each coefficient. A $t$ statistic of 1.67 is significant at $10 \%$. 
Table 30

DISTRIBUTION OF TOTAL EXPORTS OE APR COUNTRIES TO THE UNITED STATES AND OTHER SELECTED COUNTRIES AND REGIONS, 1963, 1970, 1980, AND 1984 (in percentages)

\begin{tabular}{|c|c|c|c|c|c|c|}
\hline & & 1963 & & & 1970 & \\
\hline & ADCs & $\underline{\mathrm{RRCs}}$ & China & $\underline{A D C s}$ & $\underline{\mathrm{RRCS}}$ & China \\
\hline United States & 18.5 & 19.0 & - & 37.0 & 17.9 & - \\
\hline Canada & 1.7 & 0.8 & - & 2.8 & 0.7 & - \\
\hline Japan & 11.2 & 20.9 & - & 11.9 & 25.0 & - \\
\hline Australia \& NZ & 3.8 & 1.1 & - & 2.8 & 1.7 & - \\
\hline $\mathrm{EC}$ & 23.8 & 18.9 & - & 18.2 & 14.6 & - \\
\hline ADCs & 12.3 & 31.6 & - & 15.1 & 33.8 & - \\
\hline RRCs & 28.1 & 7.2 & - & 11.3 & 5.5 & - \\
\hline China & 0.3 & 0.0 & - & 0.5 & 0.4 & - \\
\hline & $1 \overline{00.0}$ & $1 \overline{00.0}$ & & 100.0 & $1 \overline{00.0}$ & \\
\hline & & 1980 & & & 1984 & \\
\hline & $\underline{\text { ADCs }}$ & $\underline{\mathrm{RRCs}}$ & China & ADCs & $\underline{\mathrm{RRCS}}$ & China \\
\hline United States & 24.6 & 16.4 & - & 34.4 & 18.7 & 12.1 \\
\hline Canada & 1.7 & 0.3 & - & 2.4 & 0.4 & 1.3 \\
\hline Japan & 10.5 & 31.8 & - & 10.9 & 36.8 & 26.9 \\
\hline Australia \& NZ & 3.7 & 1.6 & - & 2.8 & 2.0 & 1.3 \\
\hline EC & 18.9 & 12.3 & - & 13.4 & 8.4 & 11.5 \\
\hline ADCs & 16.7 & 31.0 & - & 14.2 & 27.9 & 42.7 \\
\hline RRCs & 22.1 & 5.6 & - & 19.2 & 4.9 & 3.9 \\
\hline & $1 \overline{100.0}$ & 100.0 & & 100.0 & 100.0 & $1 \overline{00.0}$ \\
\hline
\end{tabular}

Source: UNCTAD Trade Data tape. 
Table 31.

OUTSTANDING DIRECT INVESTMENT, 1980

(million $\$$ )

\begin{tabular}{|c|c|c|}
\hline Investment by: & United States & Japan \\
\hline Investment in: & Amount & Amount \\
\hline Japan & 6,274 & -- \\
\hline United States & -- & 8,878 \\
\hline South Korea & 587 & 1,137 \\
\hline Taiwan & 510 & 370 \\
\hline Hong Kong & 1,969 & 1,095 \\
\hline Indonesia & 1,334 & 4,424 \\
\hline Malaysia & 618 & 650 \\
\hline Philippines & 1,244 & 615 \\
\hline Singapore & 1,196 & 936 \\
\hline Tha iland & 360 & 396 \\
\hline \multirow[t]{2}{*}{ Subtotal: ASEAN } & 4,752 & 7,021 \\
\hline & 7,818 & 9,623 \\
\hline World Total & 213,460 & 36,497 \\
\hline
\end{tabular}

a ADME stands for Advanced Developing Market Economies.

Source: Hugh Patrick, "The Asian Developing Market Economies -- How They Have Affected and Been Affected By the United States-Japan Economic Relationship." Paper presented at conference, The United States, Japan, and Southeast Asia: The Issues of Interdependence, Maui, Hawai $i$, December 14-18, 1983. 
Table 32.

PERCENTAGE COUNTRY SHARES OF ALL U.S. FOREIGN

DIRECT INVESTMENT IN AN INDUSTRY, 1977

country

A11 Mining Petr. Total Food Chem. Prim. Mach. Elect. Industries Mfg. Metal exc. Eqpt.

-

Fab. Elect.

Eqpt.

Endonesia

0.7

2.6

0.2

0.0

0.3

*

0.2

Malaysia

0.3

0.1

a $\quad 0.1$

0.1

0.1

0.0

0.0

0.8

Philippines

0.6

* $\quad 1.0 \quad 0.5$

$\begin{array}{ll}1.8 & 0.7\end{array}$

0.3

0.0

0.6

Singapore

0.4

$0.0 \quad 0.8$

0.2

0.10 .0

0.6

0.1

0.8

Tha i land

0.2

0.1

a

0.1

0.20 .1

0.0

0.0

0.2

Korea

0.3

0.0

0.3

0.1

0.8

0.0

$a$

0.3

Taiwan

0.2

0.0

0.1

0.3

0.2

$0.4 \quad 0.0$

0.0

1.6

Hong Kong

0.9

$0.0 \quad 1.0$

0.3

0.1

0.4

a

0.1

1.1

\begin{tabular}{cccc}
$\begin{array}{c}\text { Transp. } \\
\text { Eqpt. }\end{array}$ & $\begin{array}{c}\text { Mfher } \\
\mathrm{fg} .\end{array}$ & $\begin{array}{l}\text { Bank- } \\
\text { ing }\end{array}$ & $\begin{array}{l}\text { Finance } \\
\text { except } \\
\text { Banking }\end{array}$ \\
\hline
\end{tabular}

Indonesia

Ma laysia

Philippines

singapore

Thail and

Korea

Taiwan

Hong Kong a

0.1

0.2

0.0

0.2

0.0

2.1

0.1

1.1

0.1

0.6

0.0

0.4

0.1

0.8

0.0

0.8

3.0

2.2

a

* Indicates an amount between $-\$ 500,000$ and $+\$ 500,000$.

a suppressed to avoid disclosure of data on individual companies.

Source: U.S. Department of Commerce, U.S. Direct Investment Abroad, 1977, Washington, D.C., April 1981. 
Table 32. (cont.)

PERCENTAGE COUNTRY SHARES OF ALL U.S. FOREIGN

DIRECT INVESTMENT IN AN INDUSTRY, 1984

\begin{tabular}{|c|c|c|c|c|c|c|c|c|c|}
\hline Country & $\begin{array}{c}\text { All } \\
\text { Industries }\end{array}$ & Mining & Petr. & $\begin{array}{l}\text { Total } \\
\text { Mfg. }\end{array}$ & Food & Chem & $\begin{array}{l}\text { Prim. } \\
\text { Metal } \\
\text { Fab. }\end{array}$ & $\begin{array}{l}\text { Mach. } \\
\text { exc. } \\
\text { Elect. } \\
\text { Eqpt. }\end{array}$ & $\begin{array}{l}\text { Elect. } \\
\text { Eqpt. }\end{array}$ \\
\hline Indonesia & 1.9 & a & 6.1 & 0.2 & 0.1 & 0.2 & a & 0.0 & 0.3 \\
\hline Malaysia & 0.5 & 0.0 & 1.1 & 0.4 & a & 0.1 & 0.1 & a & 3.1 \\
\hline Philippines & 0.5 & 0.0 & a & 0.5 & 1.1 & 0.8 & 0.4 & 0.0 & a \\
\hline Singapore & 1.0 & 0.0 & 0.8 & 1.1 & $\mathbf{a}$ & 0.5 & 1.2 & a & 5.2 \\
\hline Thailand & 0.4 & 0.2 & $\mathbf{a}$ & $\mathbf{a}$ & 0.0 & 0.2 & a & 0.0 & a \\
\hline Korea & 0.4 & 0.0 & $\mathbf{a}$ & 0.2 & 0.5 & 0.0 & a & $\mathbf{a}$ & 1.0 \\
\hline Taiwan & 0.4 & 0.0 & 0.2 & 0.5 & 0.2 & 0.6 & D & a & 1.8 \\
\hline Hong Kong & 1.6 & 0.0 & 0.5 & 0.7 & 0.2 & 0.7 & 0.9 & $\mathbf{a}$ & 2.0 \\
\hline & & $\begin{array}{l}\text { Transp. } \\
\text { Eqpt. }\end{array}$ & $\begin{array}{c}\text { Other } \\
\text { Mfg. }\end{array}$ & Trade & $\begin{array}{l}\text { Bank- } \\
\text { ing }\end{array}$ & \multicolumn{2}{|c|}{$\begin{array}{l}\text { Finance } \\
\text { except } \\
\text { Banking }\end{array}$} & $\begin{array}{c}\text { Other } \\
\text { Industries }\end{array}$ & \\
\hline Indonesia & & 0.0 & $\mathbf{a}$ & 0.2 & 0.2 & \multicolumn{2}{|c|}{0.0} & a & \\
\hline Malaysia & & a & 0.2 & 0.3 & 0.1 & \multicolumn{2}{|r|}{$a$} & $\mathbf{a}$ & \\
\hline Philippines & & $\mathbf{a}$ & $\mathbf{a}$ & 0.2 & 2.0 & \multicolumn{2}{|r|}{$\mathbf{a}$} & $\mathbf{a}$ & \\
\hline Singapore & & a & a & 1.0 & 1.6 & \multicolumn{2}{|c|}{0.5} & 0.8 & \\
\hline Tha i land & & $a$ & a & 0.2 & 0.4 & \multicolumn{2}{|c|}{0.0} & a & \\
\hline Korea & & 0.3 & 0.1 & 0.4 & 1.6 & \multicolumn{2}{|r|}{ a } & a & \\
\hline Taiwan & & 0.2 & a & 0.4 & 0.9 & \multicolumn{2}{|c|}{0.0} & 0.1 & \\
\hline Hong Kong & & 0.0 & $\mathbf{a}$ & 3.7 & 3.9 & \multicolumn{2}{|c|}{4.2} & 4.7 & \\
\hline
\end{tabular}

a suppressed to avoid disclosure of data on individual companies.

Source: U.S. Department of Commerce, U.S. Direct Investment Abroad, 1977 , Washington, D.C., April 1981. 
Table 33.

PERCENTAGE INDUSTRY DISTRIBUTION OF A COUNTRY'S TOTAL

DIRECT INVESTMENT FROM THE UNITED STATES, 1977

Mining Petr. Total Food Chem. Prim. Mach. Elect. Mfg. Metal exc. Eqpt.

Country

Indonesia

Malaysia

Malaysia

Philippines

Singapore

Thai land

Korea

Taiwan

Hong Kong

Indonesia

Malaysia

Philippines

Singapore

Thail land

Korea

Taiwan

Hong Kong

$74.8 \quad 9.9$

$0.2 \quad 3.0$

a $\quad 18.5$

$0.6 \quad 3.2$

$\begin{array}{llll}32.6 & 37.9 & 11.9 & 10.5\end{array}$

$\begin{array}{llll}45.0 & 20.5 & 1.0 & 0.6\end{array}$

a $\quad 21.5$

$3.8 \quad 3.8$

$2.0 \quad 22.8$

0.3

$0.4 \quad 1.2$

a $\quad 1.2$

$\begin{array}{llll}20.4 & 15.1 & 0.4 & 3.8\end{array}$

0.0

6.2

68.7

$\begin{array}{ll}3.5 & 19.7\end{array}$

Transp. Other Eqpt.
Elect.

Eqpt.

$0.4 \quad 0.9 \quad 9.9$

$\begin{array}{lll}1.7 & 0.1 & 4.1\end{array}$

$\begin{array}{lll}5.4 & 2.9 & 8.7\end{array}$

$\begin{array}{lll}1.7 & 0.0 & 4.6\end{array}$

$0.3 \quad$ a $\quad 4.3$

4.3

34.0

4.4

\begin{tabular}{|c|c|c|c|c|c|}
\hline $\begin{array}{c}\text { Transp. } \\
\text { Eqpt. }\end{array}$ & $\begin{array}{l}\text { Other } \\
\text { Mfg. }\end{array}$ & Trade & $\begin{array}{c}\text { Bank- } \\
\text { ing }\end{array}$ & $\begin{array}{l}\text { Finance } \\
\text { except } \\
\text { Banking }\end{array}$ & $\begin{array}{c}\text { Other } \\
\text { Industries }\end{array}$ \\
\hline
\end{tabular}

$\begin{array}{llllll}0.0 & \text { a } & 0.9 & 0.8 & 0.5 & \text { a }\end{array}$

$\begin{array}{llllll}\text { a } & 3.2 & \text { a } & 1.7 & 0.4 & 3.0\end{array}$

$\begin{array}{llllll}\text { a } & \text { a } & 9.1 & 11.1 & 3.1 & 6.2\end{array}$

$\begin{array}{llllll}0.2 & 1.7 & 14.5 & 9.5 & 3.5 & 7.2\end{array}$

0.0

7.6

a $\quad 11.4$

2.5

3.4

$\begin{array}{llllll}\text { a } & 1.3 & \text { a } & 4.3 & 2.8 & 2.3\end{array}$

$\begin{array}{llllll}2.7 & 6.9 & 8.5 & 13.9 & 1.9 & 0.8\end{array}$

0.0

a $\quad 28.2 \quad 10.0$

12.3

13.9

${ }^{a}$ suppressed to avoid disclosure of data on individual companies.

Source: U.S. Department of Commerce, U.S. Direct Investment Abroad, 1977, Washington, D.C., Apri1 1981. 
Table 33. (cont.)

PERCENTAGE INDUSTRY DISTRIBUTION OF A COUNTRY'S TOTAL

DIRECT INVESTMENT FROM THE UNITED STATES, 1984

\begin{tabular}{|c|c|c|c|c|c|c|c|c|}
\hline Country & Mining & Petr. & $\begin{array}{l}\text { Total } \\
\text { Mfg. }\end{array}$ & Food & Chem. & $\begin{array}{l}\text { Prim. } \\
\text { Metal } \\
\text { Fab. }\end{array}$ & $\begin{array}{l}\text { Mach. } \\
\text { exc. } \\
\text { Elec. } \\
\text { Egpt. }\end{array}$ & $\begin{array}{l}\text { Elec. } \\
\text { Eqpt. }\end{array}$ \\
\hline Indonesia & $a$ & 88.3 & 3.4 & 0.3 & 0.9 & a & 0.0 & 0.6 \\
\hline Malaysia & 0.2 & 62.4 & 32.1 & $\mathbf{a}$ & 2.5 & 0.8 & $a$ & 23.2 \\
\hline Philippines & 0.0 & a & 37.4 & 8.8 & 15.0 & 1.9 & 0.4 & $a$ \\
\hline Singapore & 0.0 & 24.0 & 45.4 & a & 4.3 & 3.4 & $a$ & 20.4 \\
\hline Thai land & 1.1 & $a$ & $a$ & 0.2 & 4.8 & a & 0.0 & $\mathbf{a}$ \\
\hline Korea & 0.0 & a & 25.6 & 5.7 & 1.1 & a & $a$ & 10.2 \\
\hline Taiwan & 0.0 & 12.8 & 56.0 & 1.9 & 15.6 & 0.0 & a & 19.1 \\
\hline Hong Kong & 0.0 & 9.2 & 16.6 & 0.5 & 3.8 & 1.4 & $a$ & 4.7 \\
\hline & $\begin{array}{c}\text { Transp. } \\
\text { Eqpt. }\end{array}$ & $\begin{array}{l}\text { Other } \\
\text { Mfg. }\end{array}$ & Trade & $\begin{array}{l}\text { Bank- } \\
\text { ing }\end{array}$ & \multicolumn{2}{|c|}{$\begin{array}{l}\text { Finance } \\
\text { except } \\
\text { Banking }\end{array}$} & $\begin{array}{c}\text { Other } \\
\text { Industries }\end{array}$ & \\
\hline Indonesia & 0.0 & a & 1.2 & 0.7 & \multicolumn{2}{|c|}{0.2} & $a$ & \\
\hline Malaysia & $a$ & 3.6 & 8.3 & 1.6 & \multicolumn{2}{|r|}{$a$} & a & \\
\hline Philippines & a & a & 4.6 & 22.0 & \multicolumn{2}{|r|}{ a } & a & \\
\hline Singapore & $a$ & a & 13.7 & 9.4 & \multicolumn{2}{|c|}{3.2} & 4.3 & \\
\hline Thailland & 0.0 & a & 7.9 & 5.7 & \multicolumn{2}{|c|}{0.2} & a & \\
\hline Korea & 3.5 & 2.6 & 13.2 & 26.1 & \multicolumn{2}{|r|}{$a$} & a & \\
\hline Taiwan & 3.1 & a & 14.5 & 13.8 & \multicolumn{2}{|c|}{0.7} & 2.2 & \\
\hline Hong Kong & 0.0 & a & 30.0 & 13.5 & \multicolumn{2}{|c|}{15.7} & 15.1 & \\
\hline
\end{tabular}

